\title{
El Niño con su Padre de Fray Diego Padilla ${ }^{1}$
}

\author{
The Boy with his Father by Fray Diego Padilla
}

\author{
A Criança com seu Pai de Frei Diego Padilla
}

\author{
Fernando Campo del Pozo ${ }^{2}$ \\ Colegio de San Agustín - España \\ Grupo de investigación ILAC \\ fernandocampo@picos.com
}

Recepción: 02/03/2013

Evaluación: 11/07/2013

Aceptación: 15/05/2014

Artículo de Revisión

\section{RESUMEN}

Con este artículo se procura dar a conocer el pensamiento pedagógico del P. fray Diego Francisco Padilla, en un opúsculo titulado El Niño con su Padre, del que se hace un estudio y se reproduce. Diego Padilla fue el agustino más conspicuo de la Ilustración en América a finales del siglo XVIII y comienzos del XIX. Siendo criollo e ilustrado, promovió la filosofía moderna y la educación popular. Era un poco enigmático al no firmar sus libros. En la introducción se analizan algunas facetas de su vida y obras, como educador y promotor de la Independencia del Nuevo Reino de Granada. Fue profesor universitario, provincial y párroco con dotes de gobierno y de periodista. Para el año 1809, tenía ya escritos 49 opúsculos "sobre el modo y circunstancias de hacer feliz" a su patria, a la que sirvió redactando el Acta de la Independencia de Colombia y llegó a ser presidente del Congreso. Fue amigo de Antonio Nariño y de Simón Bolívar. Estuvo preso y sufrió el destierro por defender la independencia de América y los derechos humanos. Fue neo-rousseauniano en economía y tradujo al castellano el tratado de Economía de J. J. Rousseau. Le contradijo en educación, refutando el Emilio con su libro El Niño con su Padre, que es un modelo de educación cívica, integral y cristiana.

1 Este trabajo es resultado del proyecto de investigación Discursos Políticos de Criollos Ilustrados en las Independencias Americanas (código SGI: 1128), avalado por el Consejo Superior de Investigaciones Científicas (CSIC) y la Universidad Pedagógica y Tecnológica de Colombia (UPTC). Esta investigación fue desarrollada por el grupo Ilustración en América Colonial (ILAC), reconocido y visible por Colciencias.

2 Doctor en Derecho Civil y Canónico. Miembro correspondiente de la Academia Boyacense de Historia y de la Academia de Historia de Venezuela en Caracas. Miembro del Instituto Histórico Agustiniano con sede en Roma y de la Academia de la Hispanidad. Miembro del grupo de investigación Ilustración en América Colonial (ILAC), adscrito a la UPTC. 
Palabras clave: Revista Historia de la Educación Latinoamericana, independencia de América, Economía, educación y libertad.

\section{ABSTRACT}

This article aims at presenting the pedagogical thought of Father Fray Diego Francisco Padilla, in a pamphlet entitled The Boy in his Father, where emerged a study it is made and played. Diego Padilla was the most agustinian conspicuous of the american enlightment in the late eighteenth and early nineteenth centuries. As an illustrated Creole he was pioneer in the modern philosophy and popular education. He was a bit puzzling to not sign his books. The introduction discusses some facets of his life and works, as an educator and promoter of the independence of the new Kingdom of Granada. He was parish priest, provincial and university professor with skills of governor and journalist. In 1809, he had already written 49 booklets "on the way and circumstances to make happy" to his homeland, he served that drafting the Act of independence of Colombia and became President of the Congress. . He was a friend of Antonio Nariño and Simon Bolivar. He was prisoner and he suffered the exile for defending the independence of America and the human rights. He was neo-rusonian in economy and he translated into Spanish the treaty of Economy of J. J. Rousseau. He contradicted in education, refuting the Emilio with his book The boy with his father, who is a complete model of civic ans Christian education.

Key words: Journal History of the Latin American education, independence of America, economy, education and freedom.

\section{RESUMO}

Com este artigo se procura dar a conhecer o pensamento pedagógico de P. Frei Diego Francisco Padilla, em um opúsculo intitulado A criança com seu pai, em que faz um estudo e o reproduz. Diego Padilha foi o agostiniano mais notável da ilustração na América no final do século XVIII e começo do XIX. Sendo crioulo e ilustrado, promoveu a filosofia moderna e a educação popular. Era um pouco enigmático al não assinar seus livros. $\mathrm{Na}$ introdução se analisam algumas facetas de sua vida e obras, como educador e promotor da independência do Novo Reino de Granada. Foi professor universitário, provincial e pároco com dotes de governo e periodista. Até o ano de 1809, teve escritos 49 opúsculos "sobre o modo e circunstâncias de fazer feliz" a sua pátria, a que serviu redigindo a Ata da Independência da Colômbia e chegou a ser presidente do Congresso. Foi amigo de Antonio Nariño e de Simón Bolívarívar. Esteve presoívar. Esteve preso e sofreu o exílio por defender a independência da América e os direitos humanos. Foi neo-russoniano em economia e traduziu ao castelhano o tratado de Economia de J.J. Rosseau. Se opôs a ele na educação, refutando o Emílio com seu livro A criança com seu pai, que é um modelo de educação cívica, integral e cristã.

Palavras-chave: Revista História da Educação Latino-americana, independência da América, Economia, educação y liberdade. 


\section{INTRODUCCIÓN}

Se ha escrito bastante sobre el P. Diego Francisco Padilla, con su vida ${ }^{3}$ y obras ${ }^{4}{ }^{\text {analizando }}$ algunos aspectos relevantes como filósofo, teólogo, político, promotor de la independencia, economista y algo como pedagogo. Quedan algunas facetas aún sin clarificar, como las que aparecen en El Niño con su Padre, publicado en los últimos años de su vida. ${ }^{5}$ En sus páginas se nota un latido vital de este gran pedagogo, promotor de los estudios universitarios y de la educación popular en la República de Colombia; por eso conviene darle a conocer según el libro El Niño con su Padre.

En este opúsculo demuestra su gran cultura y cómo seguía el curso de los estudios en Europa y América con una defensa del derecho a la educación. Había que consolidar a la naciente nación sobre los pilares de la libertad y la democracia, con una autonomía administrativa y progresista. Él es el representante más conspicuo del método y de la escuela agustiniana en Hispanoamérica en el siglo XVIII. ${ }^{6}$

Un resumen de su vida y obra aparece en la placa que se le ha colocado en la iglesia de San Agustín de Bogotá, donde reposan sus restos: “In Memoriam. La Provincia Agustiniana de Nuestra Señora de Gracia de Colombia rinde homenaje a un hijo religioso y Prócer de la Independencia. El Padre Fray Diego Francisco Padilla Rico Osa. Nació el 12 de noviembre de 1751 y murió el 9 de abril de 1829. En este templo de San Agustín yacen sus restos mortales. Bogotá, mayo 8 de 2012, día de la Provincia de Nuestra Señora de Gracia".

Con la colocación de esta placa se hace justicia al P. fray Diego F. Padilla, que quiso orientar al pueblo americano, especialmente al de Nueva Granada, en la educación y enrumbamiento democrático hacia la Gran Colombia. Trató en su época de conciliar la fe con la cultura según la Ilustración, dentro de una orientación apologética y científica, como profesor en la Universidad de San Nicolás de Bari en Bogotá y luego como párroco de Bojacá, donde para el año 1810 "había escrito 49 Opúsculos sobre el modo y circunstancias de hacerla feliz"7 (a la patria) y han desaparecido casi todos. Quizás este sea uno de ellos, revisado durante los últimos años de su vida en Bojacá, donde había establecido una escuela para adultos, además de la existente para niños. Se conserva un solo ejemplar de El Niño con su Padre, que convine estudiar y dar a conocer dado su valor. José María Vergara llegó a ver varios

3 Agustín Fernández, Oración fúnebre en las honras que hizo el convento de agustinos calzados de Bogotá el día 18 de Mayo de 1820 a la feliz memoria de su hijo y padre N. M. R. P. Maestro Fray Diego Francisco Padilla (Bogotá: Imprenta de Bruno de Espinosa. Por José Ayarza, 1829), 39.

4 Fernando Campo del Pozo, "Fray Diego F. Padilla, educador y prócer de la Independencia de la Gran Colombia. En Educadores en América Latina y el Caribe de la colonia al siglo XIX y XX, eds. Diana Soto Arango, Jesús Paniagua Pérez, José Rubens Lima Jardilino y María Cristina Vera de Flachs (Tunja: Ediciones Doce Calles, 2011), 47-81; Mauricio Saavedra, Lista crítica de los escritos del Reverendo Padre Diego Francisco Padilla. O.S.A., (1751-1829) (Tesina de graduación en el Instituto Agustiniano de Estudios Superiores. Facultad de Filosofía, en Bogotá, 2003), 60-94; Francisco Javier Campos, El P. Diego Francisco Padilla y el "Aviso al Público" (San Lorenzo de El Escorial: Ediciones Escurialenses, 2011), 59-72.

5 Diego Padilla, El Niño con su Padre (Bogotá: Imp. de Espinosa, por Valentín Rodríguez Molano, 1824), 59. Se encuentra en la Biblioteca Nacional de Colombia, Bogotá, Fondo Pineda, 726, MF 213. Está el texto completo, aunque hay algunos fallos de paginación en la p. 8 y 56-58, que se omiten y se saltan. No aparece su nombre y se menciona entre sus obras por A. Fernández, Oración fúnebre, 22.

6 Fernando Campo del Pozo, "Fray Diego Francisco Padilla ilustrado y pedagogo", en Científicos criollos e Ilustración, eds. Diana Soto Arango, Miguel Ángel Puig-Samper y María Dolores González-Ripoll (Madrid: Ediciones Doce calles, COLCIENCIAS, RUDECOLOMBIA, 1999), 123-234; "El modelo universitario en América”, en Autonomía y Modelos Universitarios en América Latina, eds. Diana Soto Arango y María Isabel Guantes (León: Universidad, 2007), 27-63.

7 Fernández, Oración fúnebre, 23. El P. Padilla fue también un inspirado y buen poeta. 
manuscritos encuadernados del P. Diego F. Padilla en la biblioteca del convento san Agustín de Bogotá. ${ }^{8}$

\section{Composición de El Niño con su Padre y su publicación en 1824}

Siendo párroco de Bojacá y con muchos años de experiencia docente y pastoral, dio a conocer El Niño con su Padre, que podía estar ya compuesto desde antes y fue mejorado como fruto de sus catequesis y clases parroquiales. Apareció en siete fascículos desde el 8 de enero hasta el 8 de agosto de 1824. Está escrito en forma de diálogo sobre los malos libros, entre los que incluye especialmente el libro de J. J. Rousseau, Emilio, o De la educación y la Julia, o la Nueva Eloisa (Eloysa y Abelardo), que él llevó en 1786 al Nuevo Reino de Granada con otros de la Enciclopedia Francesa, como el Tratado de Economía Política de Rousseau, ${ }^{9}$ que tradujo y publicó como suplemento del Aviso al público. Se ve la gran erudición que tenía y cómo estaba al tanto de los libros que se publicaban. Es lamentable que una obra como El Niño con su Padre haya permanecido marginada y olvidada.

Quería formar buenos ciudadanos, como J. J. Rousseau, pero con una ética cristiana, sin perder de vista la vida doméstica y civil. Refutó a Rousseau que quiso marginar a Dios en la educación de los niños, antes de los 18 años, aunque la admitió para las niñas. Rousseau, en su religión naturalista y deísmo, reconoció a su manera el sentido religioso de la voz de la conciencia que todos tenemos, como verdadera guía del hombre. Hay una amalgama indigesta en J. J. Rousseau con su etapa de protestante y luego de católico, resultando heterodoxo, por lo que su Emilio fue rechazado por católicos y protestantes. Rousseau siguió el materialismo del barón de Holbach, autor del Sistema de la Naturaleza, que fray Diego F. Padilla censuró en un folio sin fecha, donde aparece su nombre. ${ }^{10}$ Rousseau corrigió en parte el materialismo ateo de Holbach, al ver a Dios en la naturaleza. Su pensamiento sobre la religión lo expuso en el libro $4^{\mathrm{o}}$ con la célebre Profesión de fe del vicario saboyano, que deja mucho que desear y que conviene tener en cuenta. ${ }^{11}$ Necesitaba de una corrección crítica y seria como lo intentó hacer el P. Diego F. Padilla en su tiempo con este libro.

El Niño con su Padre apareció en forma de semanario. Los tres primeros números aparecieron los días jueves y los cuatro últimos los días domingo, procurando repartirlos entre sus alumnos y el pueblo. Tiene un total de 59 páginas numeradas, aunque de hecho no son más que 56, al saltarse la página 8 y luego desde la 56 hasta la 58, como se ha observado antes.

Aunque no lo firmó, se sabe que es de él porque lo menciona entre sus obras el P. Agustín Fernández. $^{12}$ Es poco conocido este opúsculo. Su importancia ha sido reconocida por el benemérito historiador, crítico y buen amigo Mons. Mario Germán Romero. ${ }^{13}$

8 José María Vergara y Vergara, Obras escogidas, vol. 3, Biografías (Bogotá: Edit. Minerva, 1931), 40.

9 Oreste Popescu, Un Tratado de Economía Política en Santafé de Bogotá, en 1810. El enigma de Fray Diego Padilla (Bogotá: Imprenta de Salazar 1968), 98.

10 Diego F. Padilla, “Censura al libro Sistema de la Naturaleza del Barón D’Holbach”, en Diccionario filosófico, teológico y científico, ms. 416, sin fecha. Se encuentra en la Biblioteca Nacional de Colombia (BANC), Bogotá, Colombia, sin fecha, f. 13, donde aparece la censura condenatoria. El ms. tiene 157 folios, con distintas letras. Perteneció al P. Diego F. Padilla, que puso anotaciones sobre la Revolución francesa. Hay variación de letras con textos en latín y en castellano.

11 Jean Jacques Rousseau, Emilio o la Educación, ed. Angeles Cardona de Gilbert y Agustín González Gallego (Barcelona: Ediciones Bruguera, 1976), 52-53.

12 Fernández, Oración fúnebre, 22

13 Mario Germán Romero, "Fray Diego Francisco Padilla”, en Próceres 1810 en el Sesquicentenario de la Independencia, eds. por Juan Lozano y otros (Bogotá: Banco de la República, 1960), 31. 


\section{El porqué de esta obra y su orientación pedagógica}

Sorprende cómo él, que fue eminente profesor universitario y destacado político, supo acomodarse al público dentro de unas circunstancias conflictivas, con gran habilidad pedagógica y sentido cristiano. Puso al principio de cada número una frase latina, como era costumbre en su época y se siguió practicando hasta pasado el medio siglo XX, al comenzar los discursos y sermones eclesiásticos. A pesar de estar escrito con sencillez y elegancia, tiene frases y expresiones muy atrevidas como la de un escritor modernista y hasta naturalista. Su pluma posee brillantez, calor y lozanía con atrevidos escorzos de pinceladas humanas. Defensor de la libertad de su patria, se muestra como maestro educador de niños, reconociendo el derecho primario de los padres en la formación de sus hijos. Buen conocedor del latín y del idioma hispano, sabe conjugar la sencillez con la habilidad estilística. Esto va unido a una imaginación patriótica y expresiva de vivo realismo. No pierde de vista el soporte religioso-evangélico. Pone en este opúsculo el ímpetu de su temperamento como en el Aviso al público, donde aparece su personalidad literaria como pensador, filósofo, político de altura y forjador de nuevas ideas culturales y democráticas. La humildad y la prudencia le llevaron a ocultar su nombre cuando era muy conocido en su entorno, especialmente en la élite neogranadina. Pensaba en la Gran Colombia. Se había retirado a un pueblecito de Bojacá, en la sabana de Bogotá, donde las casas se concentraban en torno a la Virgen de la Salud, con su iglesia y escuela rural.

El P. Diego Francisco Padilla consideró fundamental algo en lo que no había pensado Rousseau, al reconocer el derecho fundamental de los padres en la educación de sus hijos según su religión. Rousseau se propuso hacer un plan de educación para ser evaluado por los expertos y no en un método para los padres y madres. Reconoció el papel de la "tierna y prudente madre", a la que menciona en el libro primero. ${ }^{14}$ Padilla intentó, como san Agustín, elaborar un tratado de educación cristiana para el mundo americano. Criticó a Rousseau que no llegó a conocer, al "hombre natural" como sucedía en la realidad de los pueblos aborígenes indígenas de América, en los que había un instinto o sentimiento religioso de diversa índole. El hombre es por naturaleza social y religioso, y la educación no es integral si le falta ese sentimiento, como la educación física o sexual, además de la intelectual.

Al ser un hombre muy culto, el P. Padilla llegó a conocer los principales temas y publicaciones de su tiempo, como los de la Enciclopedia francesa, especialmente a Rousseau, del que tradujo el Tratado de Economía Política y le refutó en El Niño con su Padre.

\section{Desarrollo de contenidos y estructura de este opúsculo}

Comienza preguntando un niño a su padre: “¿Hoy he dado bien la lección? Sí hijo mío, la has aprendido perfectamente. ¿Qué quieres pedirme?". ${ }^{15}$ El niño le pidió un libro muy bonito por fuera, que el profesor de música le había ofrecido a su hermana. Al decirle que se titulaba Cartas de Heloysa y Abelardo, el padre se sorprendió observando que era un "mal librito". Se alegró el buen padre de saber que su hija había rechazado el libro, porque no se lo había regalado él y no lo aceptaba sin su permiso. Le observó a su hijo que "una cosa no es buena porque lo exterior sea hermoso: el veneno suele estar encerrado en una píldora dorada". Para demostrar esto, observó que había comprado una bacinilla de plata. Le dijo que al día siguiente la recogiese de la recámara y se la llevase al gabinete, como estuviese. El niño observó: “Gai, gai, Papá, no me digas eso que me hace vomitar". El mismo niño reconoció que tenía "K K". Eso pasaba con

\footnotetext{
14 Rousseau, Emilio, 65. Rousseau quedó pronto huérfano de madre y su padre le abandonó a los 10 años. Se encargó de él un tío materno, por lo que va a tener una vida azarosa, siendo revolucionario.

15 Padilla, El Niño con su Padre, 1.
} 
los malos libros que la misma Iglesia prohibía. Semejaban al riachuelo que iba junto al convento de san Agustín en Bogotá, donde había que tapar la nariz al pasar su puente. Luego expuso quiénes eran Abelardo y Eloisa, cuyo libro había leído, como persona mayor, alegando que él podía beber un vaso de vino con algo de agua y el niño no.

A partir del diálogo del número $2^{\circ}$ observa que "no conviene saber más de lo que conviene" y relata cómo Adán y Eva pecaron por comer de la fruta prohibida y querer ser como Dios. Algo parecido sucede con los malos libros que despiertan las pasiones y dañan a los jóvenes. Después de decirle cómo habían sido Voltaire y Rousseau, le propuso en el No. 4 traducir el libro del francés al castellano, como lección. Aunque alegó que no sabía bien esa lengua, llegó a traducir: "Predicción de un viejo manuscrito sobre la Nueva Heloysa, romance de J. J. Rousseau". ${ }^{16}$ Sigue traduciendo y observa que llega a decir: "Sólo entre los salvajes hay virtud". Su padre observó que él no había vivido nunca entre ellos. Le hizo ver otros grandes errores y que fomentaba el odio. Menciona como obras malas: "Cartas filosóficas, la muchacha de Orleán, el Tratado de la tolerancia y otras obras de Voltaire, el Espíritu de Helvesio, La nueva Eloisa y Abelardo y el Emilio de Rousseau", etc. Le demostró que había contradicciones en la obra de Rousseau.

Después de refutar estas obras dañinas, como el Emilio y otros libros llenos de herejías, al preguntarle el niño qué le propone para las vacaciones, el padre le sugiere que aprenda el latín. Cuando el niño alega que es una lengua muerta, le observa que fue y es muy importante para poder leer obras antiguas que estaban en esa lengua.

\section{CONCLUSIÓN}

En este artículo de investigación crítica y de revisión sobre el libro El Niño con su Padre, se llega a las siguientes conclusiones:

Se trata de todo un tratado de pedagogía según los principios de aquella época moderna y, en parte también, de la actual. Cada capítulo está encabezado por una frase latina de autores clásicos y de La Biblia que refleja su contenido, como se hacía con los sermones, sin que llegue a ser un sermón, sino una colección de charlas dialogadas semejantes a los sermones que hacía san Agustín, dialogando con su pueblo o con sus discípulos cuando era profesor de Retórica, para explicar la doctrina cristiana. Había que educar a la familia en la fe cristiana.

1. El P. Padilla tuvo el propósito de corregir el Emilio de Rousseau y los malos libros para educar "al buen ciudadano" con valores cristianos y teniendo muy en cuenta el fenómeno religioso. Procuró hacer también una filosofía y teología de la educación con principios éticos y morales que están en la conciencia de todo hombre. Lo que san Agustín llamó ley eterna o divina que "manda conservar el orden natural y prohíbe perturbarlo". ${ }^{17}$ En ella se apoya la ley natural, escrita en el corazón del hombre.

2. El P. Diego Padilla defendió la educación de la mujer y sus derechos frente a Rousseau, que la dejó malparada en el Emilio, y condenó la novela Abelardo y

16 Jean Jacques Rousseau, Julie, au la Nouvelle Héloïse. Lettres de deux amants. (Ámsterdam: Chez Marc Michel Rey, 1761). El P. Padilla pudo usar esta edición o la de sus obras, en Geneve, A. Neuchatel, 1764.

17 San Agustín, “Contra Fausto Maniqueo, lib. 22, cap. 27", en Obras Completas, vol. 3 (Madrid: Biblioteca de Autores Cristianos, BAC, 1993), 540. 
Eloisa. Hizo ver los peligros de la lectura de estos y otros libros, condenados por la Iglesia, que estaba sufriendo ataques de algunos enciclopedistas como Voltaire y Rousseau, junto con otros que menciona expresamente, insistiendo en los derechos y la obligación que tienen los padres en la educación de sus hijos. Se debía educar en la fe de la familia.

3. No se trata de un "breve catecismo" como opinó el P. Francisco Javier Campos, ${ }^{18}$ aunque tenga algo de parecido a los catecismos en su estructura y forma de diálogo. Su contenido es mucho más profundo como se ha visto al tratar de su razón de ser y orientación. Tiene un aspecto catequético y es más bien un buen tratado de pedagogía con fundamentos filosóficos y teológicos.

4. Con esta reseña y la publicación del opúsculo El Niño con su Padre, se procura dar a conocer el ideario y los principios pedagógicos del P. fray Diego F. Padilla, complementando estudios anteriores y clarificando su figura un poco enigmática al no firmar sus escritos por razones circunstanciales y por su humildad siendo un sabio. Se clarifica que, además de ser defensor de la democracia y la libertad, fue un gran pedagogo.

\section{DOCUMENTOS EL NIÑO CON SU PADRE ${ }^{19}$}

Núm. $1^{\circ}$. Bogotá, Jueves 8 enero de 1824. [1]

0 pueri fugite hinc, latet angüis in Libro [Oh niños, huid de aquí, está oculta una serpiente en el libro]. ${ }^{20}$

\section{El niño con su padre}

N. Mi Papá: ¿hoy he dado bien la lección?

P. Sí hijo mío, la has aprendido perfectamente. ¿Qué quieres pedirme? Pide lo que deseas, pues quiero regalarte.

N. Dame V. Papá, un librito como el que trajo hoy el maestro de música cuando vino a dar lección a mi hermana.

P. ¿Qué librito es ese, hijo mío, para buscarlo?

18 Campo, El P. Diego Padilla, 64.

19 Se hace la trascripción indicando la página y con grafía moderna para facilitar su lectura. Se respeta el texto original, porque nos indica el modo de hablar entonces y el nivel cultural de los santafereños. Se han corregido también algunos signos, especialmente de puntuación. Se respetan las citas como están y se procuran aclarar algunas dentro de lo posible, ya que hay deficiencias en algunas de ellas y en la maquetación del semanario, cuyas galeradas no se corregían antes de pasar a los tórculos de la imprenta, con algún salto de página, como se ha indicado. Se procura aclarar o complementar algunas notas, que en el original van con letras. Quedan las notas originales, como están en el texto, y se complementan algunas. Se intentó compulsar las notas de Rousseau en ediciones que hay en la Biblioteca de Viena y no se pudo lograr, aunque coincidían algunas citas, no correspondían con la paginación o foliación del texto. Hay allí copias manuscritas, lo mismo que en Ginebra, por donde pasó el P. Padilla, que da la impresión de usar varios libros con p yf.

20 Ovidio Naso, Tercera Égloga, verso 93, donde aparece: Frigidus, o pueri, fugite hinc latet angüis in herba. El P. Padilla pone libro en vez de hierba, porque le interesa. 
N. Un librito muy bonito de tafilete encarnado, doradito: es muy precioso, y el maestro se lo ofreció a mi hermana.

P. Pero ¿qué título tiene el tal librito? ¿O cómo se llama?

N. Se llama: Cartas de Heloysa y Abelard; ${ }^{21}$ es muy bonito.

P. ¡Oh hijo mío! Pídeme otra cosa: ese es un mal librito. Pero dime ¿con qué / [2] objeto te mostró el maestro de música ese librito?

N. Se lo mostró á mi hermana antes de dar la lección.

P. ¿Y tu hermanita lo recibió? ¿Lo leyó?

N. No, Papá; ni lo recibió, ni lo leyó; dijo al maestro: que ella no quería leer más libros, que los que V. le daba, y se puso colorada.

P. Bendiga Dios su inocencia y en ella la conserve. Si ella hubiere recibido, ó leído ese librito, no la quisiera yo tanto, como la quiero. Su modestia es incomparable.

N. Papá, V. no ha leído ese librito: mire que es muy bonito, muy bonito, y el maestro de música dijo á mi hermana, que contiene cosas muy bonitas, y divertidas: cómpremelo.

P. ¡El maestro de música es un malvado! Yo lo remediaré. No, hijo mío, no contiene cosas buenas, ni divertidas, sino cosas malas y perjudiciales. Yo lo he leído, y sé que es malo.

N. ¿Cómo ha de ser malo, Papá, si es tan bonito y divertido?

P. Mira, hijo mío, una cosa no es buena porque lo exterior sea hermoso: el veneno suele estar encerrado en una píldora dorada.

N. No, Papá: el librito es bueno; ¡si V. lo / [3] viera! ¡Tan bonito, tan coloradito, tan doradito! Y el maestro de música dijo a mi hermana, que lo leyera, y vería en él cosas muy alegres, y bonitas.

P. ¡O malvados! ¡Ministros de Asmodeo! ¿Hasta cuando os sufrirá la justicia de Dios? ¡He! Bien, hijo mío, ¿te ha parecido el librito por defuera muy bonito; ¿no es así?

N. Sí, mi Papá; es muy bonito, y divertido también, como dijo el maestro.

P. Pues bien. ¿Te acuerdas, que el otro día compré una bacinilla de plata, y la puse en la recámara en donde dormimos? ¿No me dijiste entonces, que te parecía muy bonita?

N. Sí Papá, ¡que bonita es, qué blanca, qué brillante! ¡Lástima que no pueda servir para la mesa! ¡Qué bonita es, Papá mío!

P. Pues bien: mañana, cuando nos levantemos de la cama, y hayamos salido de la recámara, me has de llevar a mi gabinete esa bacinilla, que te ha parecido tan bonita; pero la has de llevar conforme la hallares.

21 Jean Jacques Rousseau, Julie ou La Nouvelle Héloïse, 1. En 1772 se hizo allí mismo la tercera edición. Es tal vez la novela más famosa del siglo XVIII, escrita en forma de cartas como la antigua Eloisa y Abelardo del siglo XII, en la Edad Media, que se titulaba Cartas de Eloisa y Abelardo, con citas de la Sagrada Escritura, Séneca, Ovidio, Lucano, Horacio Cicerón, San Agustín, San Jerónimo y otros. Se divulgó también en copias manuscritas, por lo que se cita a veces por folios. Se hicieron muchas ediciones. Ya la combatió san Bernardo, que murió en 1153. La Nueva Eloisa es peor que la antigua según el P. Diego F. Padilla. Se hicieron varias ediciones y hasta copias manuscritas, así como de Emilie ou de L'Education. 
N. ¿Para qué, Papá?

P. Para que veas y consideres despacio lo que hubiere en ella, y lo registres y manosees. / [4]

N. Gai, gai, Papá, no me diga eso que me hace vomitar.

P. Pues mira, hijo mío, lo mismo te había de suceder con el librito que me pides: no solamente por defuera es bonito, sino también por dentro tiene un estilo muy fino, y unas pinturas muy vivas; pero en el centro tiene...

N. ¿Qué es lo que tiene, Papá?

P. Tiene, tiene, no sé cómo te lo diga...

N. ¿Tiene también K. K, como la bacinilla?

P. Ya tú lo dijiste: no lo quieras leer.

N. ¿Cómo ha de ser eso, Papá, si el maestro de música dijo a mi hermana, que todas las Señoritas y caballeritos lo leen?

P. Ese músico es un embustero: las niñas honradas y de educación no se emplean en leer esos libretes: ellas saben que la Iglesia lo prohíbe, y sus padres las inspiran el santo horror, que deben concebir a esa lectura. Las que leen esos libritos son las que cuidan poco de su alma, y de su honor, ó las que no tienen padres que las impidan sus riesgos y perdición.

N. Pues si son tan malos esos libritos, dígame Papá ¿como hay hombres y mujeres que los lean?

P. Cuando pasas por el puente de S. Fran / [5] cisco, ó de S. Agustín, ¿no te tapas las narices con el pañuelo, y vuelves los ojos a otra parte?

N. Sí, Papá, así es.

P. ¿Y por qué lo haces?

N. Porque me da mucho asco de ver esas inmundicias y ese olor podrido me revuelve el estómago.

P. Y no has reparado cuando vas por allí, que muchas gentes hombres y mujeres están recostados sobre el puente recibiendo el mal olor de esas sentinas, y aun en los mismos muladares no has visto gentes sentadas sobre el estiércol como sobre una alfombra de rosas y jazmín

N. Sí, Papá, lo he visto, y me he maravillado de verlos tolerar esa hediondez, rodeados de puercos y de burras, que no faltan allí.

P. Pues lo mismo sucede con esos libritos: las gentes que han perdido la delicadez de los Sentidos, de la vista y olfato, no extrañan la fetidez e inmundicia de esos lugares: y las que han perdido la delicadez de la conciencia y del honor y temor de Dios, no reparan en leer esos libros obscenos, y que inspiran corrupción. ¡A que no has visto algún Caballero, ni / [6] alguna Señorita, que se ponga á mirar despacio, ni a sentarse en el muladar!

N. No, no lo he visto jamás. 
P. Pues lo mismo sucede con esos libritos. El músico es un embustero.

N. Pero, Papá, ¿cómo dice V. que ha leído un libro tan malo?

P. Dime: cuando vamos á comer, ¿no ponen en la mesa una botella de vino?

N. Sí Señor.

P. ¿Y tú tomas de ella?

N. No, Papá, por que siendo yo todavía muy débil, me haría mucho mal, me daría calentura y dolor de cabeza, y tal vez: tabardillo, y podía morirme.

P. Pues ya ves, que yo tomo un sorbo por que lo necesita mi salud, y edad; pero ves, que lo tomo aguado, por que puro me puede dañar: así yo por mi obligación he leído ese librito; pero lo he leído con templanza y de prisa; porque aunque soy de edad, me podía hacer mucho daño: los jóvenes deben evitar con mas cuidado esos riesgos.

N. Dígame ahora Papá, ¿quienes eran esos Abelardo y Eloysa?

P. Abelardo fue hombre de mucho ingenio, pero fue muy malo, tuvo muchos errores. / [p. 7] en la $\mathrm{Fe}, \mathrm{S}$. Bernardo los combatió; y a más de eso faltó á la confianza que de él hicieron los padres de esa niña que se llamaba Eloysa: le encargaron que la diese lecciones y la enseñase las ciencias liberales: él la engañó, la pervirtió, la hizo mala, y deshonró á su familia. Pero al fin la pagó, porque se vengaron de él sus deudos.

N. ¿Qué le hicieron?

P. El mayor agravio, que se le puede hacer á un hombre.

N. ¿Cuál es ese agravio?

P. No me hagas hoy más preguntas, porque estoy muy ocupado. Si dieres bien la Lección otro día, te contaré un cuento muy bonito de una culebra. Vete á estudiar.

N. Déme V. Papá, la mano para besarla.

P. Dios te bendiga.

*Bogotá, Imp. de Espinosa; año de 182422

Núm. $2^{\circ}$ Bogotá, jueves, 15 de enero, 1824 [9]

Non plus sapere quam oportet sapere. ${ }^{23}$ [No conviene saber más de lo que conviene]

\section{El niño con su padre}

N. Papá: ya que di la lección, voy á decirle, que el Maestro de música se afirma, en que el librito es muy bueno, y dilo á mi hermana, que si V. no nos dejaba leerlo, era porque no nos ilustrásemos, y la aconsejó que no fuese simple, que se instruyese, que esos libritos son los

22 No hay 8 . Se salta esa página.

23 San Pablo, Rom 12, 3. Se dan las citas como en texto original y el modo de citar la Biblia. 
que nos han de sacar de las preocupaciones, y enseñarnos la filosofía; y que V. no quería que saliésemos de la ignorancia. ¿Es así, Papá?

P. Yo te voy á desengañar, hijo mío, de la mala fe de ese músico.

N. No, Papá mío, antes dígame V. el cuento de la culebra, que estoy desesperado por saberlo.

P. Pues oye. Dios hizo el primer jardín que / [10] ha habido en el mundo.

N. ¿Sería tan bonito como el de casa?

P. Oye: era un jardín muy grande: tenía muchos canales de agua, le plantó muchos árboles frutales, crió en él toda especie de animales; allí estaba el soberbio caballo, el manso buey, la oveja, el asno, el tigre, el león, la ardita, el conejo, y toda especie de cuadrúpedos: puso también las culebras, los sapos...

N. Ay! Papá! qué mal hizo en poner culebras en el jardín.

P. No, hijo mío: las culebras entonces no mordían, ni los tigres ni los leones eran bravos; antes venían mansitos á la mano. Pues para adornar más su jardín, puso también muchos pajaritos, el Turpial que gorjeaba como un músico, la Mirla que trinaba, el Babagúi, el Cisne, el Toche cantador, el Lorito parlero, el...

N. ¡Qué jardín tan primoroso! ¿Y esos animalitos se dejaban coger?

P. Si, hijo mío: eran todos domésticos, y venían á cantar al hombro.

N. Si yo hubiera estado allá, me habría traído un piriquito.

P. Pues ya que el jardín estuvo hecho, trajo Dios un hombre que crió, y le había casado con una mujer, y les regaló aquel / [11] jardín, y les dijo: todo esto he criado para vosotros, este jardín es vuestro, todos los animales os obedecerán, y las aves os divertirán con su canto: Ahora venid, y os diré lo que habéis de comer: entonces los sacó á pasear el jardín, y ¡cuanto fue el gusto que recibieron, cuando vieron tantos árboles frutales! Allí estaban los plátanos cargados de racimos amarillos como yema de huevo, las higueras colmadas de brevas rajadas ya de puro maduras, los duraznos de persia que destilaban miel, los melones naranjados que embalsamaban el aire con su fragancia, las ciruelas negras, las cerezas pardas, los melocotones los...

N. Papá, ¡quién hubiera entrado en el jardín ¡Se me hace la boca agua!

P. Pues ya que hubieron paseado su jardín, les dijo Dios: ¿ya habéis visto toda esa multitud de frutas? Pues de todas ellas podéis comer, todas son inocentes, á ninguno hacen mal, antes son provechosas. Pero mirad lo que os digo: de aquel árbol que está en medio del jardín, no comáis, porque es venenoso, y en el momento en que comiereis de su fruta os vendrá la enfermedad y la muerte: miradlo bien, conocedlo; yo os lo advierto, no vais á / [12] comer de él; y diciendo esto, los dejó. Ellos siguieron su camino, comiendo de las otras frutas; y un día se le antojó á la mujer salir a pasearse sola, pasó por donde estaba el árbol venenoso, y se encontró con una culebra grande, que estaba enroscada al pié del árbol, y la llamó.

N. ¡Qué! Papá, ¿las culebras hablaban?

P. El que hablaba en la culebra era el Diablo, que se había metido en ella, para engañar á la mujer. 
N. ¿Y la mujer no tuvo miedo de hablar con la culebra?

P. No, hijo mío, porque ya te he dicho, que las culebras entonces no eran bravas, ni mordían. Pues la culebra llamó á la mujer, y la dijo: ¿por qué te vas de largo, y no comes de la fruta de este árbol? La mujer le respondió: de las frutas de todos los demás árboles, como; pero de las de este árbol no puedo comer. ¿Por qué? la preguntó la culebra; y la mujer respondió: porque Dios me mandó, que no comiese, y me dijo, que si llegaba a comer me moriría. Entonces la dijo la culebra: ¿todavía estás creyendo en esas supersticiones, y fanatismos? ¿No ves, que Dios lo que quiere es, que no os ilustréis, ni salgáis de esa ignorancia, en que estáis? / [13] Dios bien sabe que si comieseis de esta fruta, seréis como unos dioses, conoceréis el bien y el mal, se abrirán vuestros ojos, os iluminaréis, saldréis de esa estupidez e ignorancia. Dios te amenazó con la muerte. Qué muerte, ni no muerte: no moriréis, ni os sucederá mal. ¡No seas simple, come, mira qué manzanas tan hermosas, y dulces! - ¿Y no es esto mismo lo que decía el músico a tu hermana?

N. Si, Papá, así le ha dicho el músico á mi hermana.

P. Pues en ese músico habla el mismo Demonio, que hablaba en la culebra.

N. Pero, Papá, ¿la mujer creyó lo que la culebra le decía?

P. Si, hijo mío, la creyó para su desgracia, y la nuestra. La curiosidad, la golosina, y el deseo de ilustrarse la perdieron.

N. ¿Que le sucedió?

P. Comió de la manzana, ${ }^{24}$ y habiendo visto venir á su marido; mira, le dijo, iqué manzana tan dulce, y tan sabrosa! Mujer, la dijo el marido ¿cómo te atreves á comer de esa fruta, que Dios nos ha prohibido? ¿No te acuerdas, que nos amenazó con la muerte, si llegásemos a probarla? Déjate de eso, respondió la mujer: ahora me ha desengañado esta culebra, y asegura, que / [14] no moriremos comiéndola: dice, que Dios, nos engaña, que no quiere que nos ilustremos, ni que sepamos lo que es bueno, y lo que es malo, ni que seamos sabios como dioses, y por eso nos la prohibió. Toma, come, como yo he comido, y verás que es fruta delicada.

N. Y el hombre ¿qué hizo?

P. El infeliz comió también, y se perdió.

N. ¿Qué le sucedió?

P. Lo que engañosamente les había predicho la culebra se les abrieron los ojos al momento, supieron lo que era el bien y el mal, y aprehendieron lo que para su felicidad habría sido conveniente ignorar.

N. ¿Qué ilustración y ciencia adquirieron?

P. Adquirieron la ciencia y conocimiento del bien que acababan de perder, y del mal que empezaban á padecer.

N. ¿Qué bien era el que perdían?

24 Gen 3, 6, donde se habla de fruto del árbol y no se precisa si era manzana, que se supuso después por añadidura de la tradición. 
P. Perdieron la inocencia, la paz del espíritu, la tranquilidad del ánimo, el imperio de la razón, la sujeción de las pasiones, y la inmortalidad.

N. ¿Y qué mal fue el que conocieron?

P. Males sin número empezaron á conocer: el primero fue la vergüenza de sí mismos, el miedo de parecer delante de Dios; luego empezaron á sentir la guerra de la carne / [15] contra el espíritu, el ruido y alboroto de las pasiones; después los animales que eran mansos, se volvieron bravos; los tigres, los leones ya les embestían, los pajaritos que venían á cantarles, se volvieron ariscos, y les huían: Dios se enojó contra ellos, los arrojó del jardín, los sentenció á trabajar para comer, y la muerte se les apareció para llevárselos. ¿No te parece, que se ilustraron mucho esos dos Esposos?

N. ¡Ay! Papá, ¡qué ilustración tan funesta! Pero dígame, Papá ¿los niños y niñas que leen esos libros del músico se ilustran del mismo modo, y conocen el bien y el mal, como ese hombre y esa mujer?

P. Si, hijo mío: al punto que los leen, se les abren los ojos, y empiezan á conocer el bien perdido, y el mal adquirido. Empiezan á sentir el ruido de las pasiones, el desasosiego del ánimo, la importunidad de las imágenes indecentes; ya no tienen sosiego, en el corazón sienten un tumulto, una inquietud, un gusano, un fuego que los abraza: ya se desvelan, lloran sin saber porqué, y empiezan á conocer el mal que les ha causado la ilustración filosófica, y el bien que perdieron y de que gozaban antes de ilustrarse. ¿No te parece buena la nueva ilustración, que ha traído esos libritos? / [16]

N. ¡O! Papá, yo no quiero ilustrarme: pero dígame ¿mataron esa mala culebra?

P. No la mataron: vive todavía en los libros, y en el pecho de esos nuevos filósofos: el demonio que habló en ella está en el infierno aguardando á los que escriben, á los que venden, á los que compran y leen esos libros de nueva ilustración.

N. Pero por fin, ¿en qué paró la culebra?

P. Dios la maldijo, la sentenció á arrastrarse, á comer tierra, y á acechar los pies de las mujeres. Lo mismo que sucede á los ilustrados de este tiempo. Ellos son malditos de Dios, se arrastran hasta igualarse con los reptiles, acechan siempre los pies de las mujeres, y se alimentan de cieno, no piensan, ni hablan, ni desean otra cosa. El jefe de los ilustrados de estos tiempos (Voltaire) $)^{25}$ llegó á comer su propio excremento, y á beber sus orines.

N. Papá, no me diga más, por que puedo soñar esta noche con las culebras.

P. Vete a estudiar.

Bogotá - Impr. de Espinosa: por Valentín Rodríguez Molano, año de 18

25 François Arouet de Voltaire (1694-1778) tuvo mucha fama y fue muy importante en su época, contando con la amistad y protección de Federico el Grande de Prusia y de Catalina de Rusia. Su principal obra es el Essai sur les moeurs et l'esprit des nations. Tuvo mucha influencia con el Diccionaire philosophique, que recoge las ideas del siglo XVIII con críticas irreligiosas y anticlericales. Llegó esta obra a manos del P. Padilla con otros escritos que condenó fuertemente por ser demoledores y dañinos en su época. El P. Padilla tiene frases muy fuertes para él. 


\section{Núm. $3^{\circ}$ Bogotá, domingo, 11 de julio, 1824 / [17]}

Non plus sapere quam oportet sapere ${ }^{26}$ [No conviene saber más de lo que conviene]

N. Me vasta, Papá mío, el que V. me mande, que no lea aquel librito, porque no quiere, que me instruya en cosas malas: pero si otros los leen, ¿qué les puede suceder?

P. Tú lo acabas de decir: leerán y aprenderán cosas malas: y esto vasta para que ningún niño lo lea. No me has dicho, que aunque el vino es sabroso, no lo probarás: ¿porque te haría mal, te causaría una fiebre, y te vendría la muerte? Pues lo mismo sucedería á otros niños, si leyesen estos libritos: perderían la salud del ánimo, se apoderaría de ellos la fiebre de las pasiones, y se expondrían á morir espiritualmente. ¿No te parece, que aquella curiosidad podía costarles muy caro? / [18]

N. Es verdad, Papá lo que V. me ha dicho otra vez, que es una imprudencia, exponerse a perder la salud corporal por una golosina, y la salud de la alma por una curiosidad.

P. Pues lo peor es, que en el mismo acto de verlos, pierden la salud espiritual, y caen en la muerte los que los leen.

N. ¿Por que? ¿Papá?

P. Por que cometen un pecado grave, y quedan excomulgados.

N. ¡Jesús Papá! Yo no sabía eso, ¿y por qué cometen un pecado grave?

P. Lo primero, por que el que se expone voluntariamente al peligro de pecar, ya peca; y lo segundo, porque falta a la obediencia, y respeto á la Iglesia de Dios, que tiene prohibida esa lectura.

N. ¿Cuándo prohibió la Iglesia la lectura de esos libros?

P. Desde el tiempo de San Pablo se daban al fuego los libros heréticos, mágicos ó / [19] impíos; y en un solo día se quemaron tantos, que su valor ascendía á cincuenta mil dineros. ${ }^{27}$ Los Concilios que se celebraron después, como son el Constantinopolitano, el Calcedonense, el Concilio II Romano, y finalmente el Concilio Tridentino ${ }^{28}$ han siempre prohibido, y anatematizado la lectura de tales libros; y un Teólogo de mucha doctrina, y virtud ${ }^{29}$ (a) dice que el librito de que se trata, y otros sus semejantes son de su naturaleza tan pestilenciales, que no se puede dar licencia para leerlos.

N. ¿Y quién da esa licencia para leerlos?

26 San Pablo, Rom 12, 3. Repite el mismo texto, ya que continúa con la materia sobre lo que conviene saber. Las citas de la Biblia se citan conforme a la terminología actual.

27 San Lucas, Hechos de los apóstoles (Hech.) 19, 19. Los fieles de Éfeso, movidos por la predicación de San Pablo, quemaron todos sus libros malos. En el Concilio de Nicea del año 325, se condenaron los libros de Arrio y en el de Éfeso del 431 los de Nestorio, etc., como en los siguientes que menciona el P. Padilla.

28 Concilio de Trento, ses. 25, cap. 21. Conciliorum Oecumenicorum decreta, ed. J. Alberigo (Bolonia: Intituto per le scienze religiose, 1983), 797. El Índice de libros prohibidos fue establecido por la Sagrada Congregación de la Inquisición o del Santo Oficio y denominada posteriormente Congregación para la doctrina de fe. El P. Diego Francisco Padilla formó parte de la Inquisición como censor y podía no sólo leer, sino también llevar y retener libros prohibidos como parte de la Enciclopedia Francesa. La censura de libros se ha reducido mucho en el Código de Derecho Canónico 1983. Ha existido y existe también por parte de las autoridades civiles. El Índice cesó de incorporar títulos en 1961 y en 1966 se decretó que no se siguiese renovando. Tenían facultades especiales los obispos para que pudiesen dispensar según los casos.

29 (a) Concin. Lib. 3, dist. 1. C: 11. No corresponde al Decreto de Graciano, no da el nombre del autor, por lo que no se ha podido identificar de momento a ese teólogo. 


\section{El Niño con su Padre de Fray Diego Padilla}

\section{P. El Sumo Pontífice.}

N. ¿Y la da á todos los que la piden?

P. La da a los profesores de teología ó Sagrados Cánones, personas doctas y piadosas, y ordinariamente con algunas excepciones que dicta la prudencia y sabiduría del que dispensa. / [20]

N. ¿Cuáles excepciones suele poner en las licencias?

P. Cuando se concede por S. S. la lectura de libros prohibidos, ordinariamente se exceptúan los libros de los heresiarcas como los de Calvino, Lutero y los que directamente, y de propósito combaten la Religión, que se llaman de primera clase. Se exceptúan también muchos, que aunque sus autores sean Católicos, pero que son sospechosos de error, que contienen errores contra la $\mathrm{Fe}$, que corrompen las buenas costumbres, que ofenden los oídos piadosos, y principalmente los que inflaman la concupiscencia, y provocan á deshonestidad y estos se llaman de segunda clase.

$\mathbf{N}$. ¿Y los que no leen, sino que oyen leer esos libros, también pecan?

P. Sí, peca también, é incurre en la excomunión, del mismo modo que incurre el que retiene el libro, y no lo entrega al ordinario, el impresor que lo imprime, los que ayudan á la impresión, los que le ministran, letra y tinta, los que los venden y compran, y todos aquellos que tienen / [21] parte en la obra, aunque esta sea un folleto de pocas hojas.

N. Papá ¿por qué será que la Iglesia ha perseguido tanto esos libros?

P. Porque los malos libros son las más poderosas armas con que el demonio vence á los hombres y llena de almas el infierno.

N. Pero esos malos libros solamente podían pervertir a los bobos; ¿más que á mí no me pervertían?

P. Es verdad, hijo mío, que los malos libros hacen la mayor presa en los simples que piensan, que todo lo que está de letra de molde, es cierto: y por eso es, que vemos tantos mozalbetes, que apenas saben leer el castellano, dar por cierto lo que han escrito los modernos herejes de Francia y de Inglaterra. Esos miserables sostienen á puño cerrado los sofismas, y cavilaciones de los incrédulos, y se confiesan ridículos, creyendo que aquellas producciones son nuevas, que están fundadas, y que no tiene respuesta. [22]

N. Papá ¿Y no es así?

P. No hijo mío: nada han escrito los nuevos filósofos, que no sea copiado de los filósofos antiguos; nada afirman, que no haya sido rebatido, y dado por falso por los Doctores Católicos hasta la demostración; nada más han hecho, que encender una negra mecha en una negra tea.

N. Pero á los que han estudiado y son Doctores; no les podrán pervertir esos libros, por que sabrán que son malos, y conocerán su falsedad.

P. Aún las personas doctas corren mucho peligro con la lección de libros heréticos, é impúdicos. El que sin licencia, y aún con licencia, pero sin necesidad se entrega á esa lectura, ordinariamente cae en error, ó en duda; y si el libro es impuro, por lo común enciende la tea de la concupiscencia. Oye lo que dice un hombre muy docto, y muy espiritual: si el que tiene licencia de S. S. para leer libros prohibidos, siente algún peligro de seducción ó perversión, y padece 
combates de graves tentaciones, peca mortalmente leyéndolos: porque la / [23] ${ }^{3}$ licencia Pontificia no le puede librar de la obligación de evitar la ocasión en que gravemente peligra. ${ }^{30}$ (é) Y ya antes te he dicho, que en las licencias para leer libros prohibidos, casi siempre se exceptúan los libros impuros y lascivos.

N. Pues entonces de nada les sirve haber estudiado, si no conocen la falsedad del libro, y se dejan engañar.

P. Advierte, que la temeridad es una especie de soberbia, y que Dios suele castigar la soberbia con caídas escandalosas; por que como dice San Agustín: unos pecados suelen ser castigo de otros pecados $^{31}$. El que siente, que a pesar de su doctrina, y sabiduría está en riesgo de pervertirse con la lección de libros malos debe abstenerse de leerlos; y si confiado en sus talentos se expone al riesgo, no es maravilla que Dios castigue su presunción dejándole caer en el lazo, que él mismo se prepara. Orígenes ${ }^{32}$ era hombre muy sabio, y la lectura de un librito lo corrompió; Marco Antonio de Dominis ${ }^{33}$, Obispo / [24] muy erudito confiesa en el prefacio de sus obras, que la lectura de unos libros le hizo apostatar, y escribir contra la Religión, contra el primado, y autoridad Pontificia, contra la eclesiástica jerarquía. Berengario ${ }^{34}$, hombre también instruido cayó en muchos errores con la lección de un libro de Juan Erigena ${ }^{35}$. Por lo cual, hijo mío, amonesto por el amor de Padre, que jamás leas libro alguno, que pueda manchar tu fe y tu pureza: sigue el consejo de San Isidoro Arzobispo de Sevilla, que decía: mejor es ignorar los errores, que exponerse a caer en ellos; menos cuenta vencer la curiosidad de leer libros tiernos, y lesivos, que pelear contra las imágenes que imprimen en la alma, y que lloran para apagar con lágrimas el fuego que encienden el corazón ${ }^{36}$.

Bogotá, Imp. De Espinosa, por Valentín Rodríguez Molano. Año de 1824

\section{Núm. $4^{\circ}$ Bogotá, Domingo, 18 de Julio, 1824}

Pinxisli venerem...

¿Et miraris, opus displicuissetum?

Martial. Epigr. ${ }^{37}$ [Heriste a Venus.... Y miras tu obra desagradable]

30 (e) Id., Ib. Al no dar el nombre del autor, libro y página, no es posible identificarlo.

31 San Agustín fue el primer expositor de la doctrina y teoría del pecado original y su transmisión. Lo hizo en varios de sus tratados como Del pecado original, 39, 44; Del libre albedrío, 3, 20; De la Ciudad de Dios, 17,11. etc.

32 Orígenes (185-254) estuvo al frente de la escuela de Alejandría y fue ordenado sacerdote sin permiso del obispo Demetrio, que le hizo huir. Estuvo algún tiempo en Palestina y luego en Grecia, donde escribió muchos libros. Se consideraban algunas de sus doctrinas heterodoxas e influyó mucho en la escolástica. Cometió el error de castrarse para evitar las tentaciones de la lujuria.

33 Marco Antonio de Dominis (1560-1624) fue obispo en Croacia y apostató pasando luego a la Iglesia anglicana. Es autor de varios libros como De república eclesiástica, Londres, 1713.

34 Berengario de Tours (1000-1008) negó la presencia real de Jesucristo en la Eucaristía y fue condenado en Concilio de París de 1051 y en Roma el año 1078.

35 Juan de Escoto Erigena (810-877) escribió varios libros, como uno Sobre la división de lo natural, que fue condenado por la Inquisición al defender cierto panteísmo.

36 San Isidoro de Sevilla, "Regula monachorum, cap. 8, n. 5”, en Obras completas, vol. 83, Patrología Latina (París: Jacques Paul Migne, 1850), 875-876, donde tiene esta frase al tratar de la biblioteca: "Gentilium libros vel haereticorum volumina monachus legere chaveat, melius est enim eorum perniciosa dogamata ignorare, quam per experientiam in aliqueum errores incurrere". Traducido al castellano: "El monje no debe leer libros de autores paganos a herejes; pues es preferible ignorar sus doctrinas perniciosas que caer en el lazo de sus errores".

37 M. Valero Marcial, Epigrammae, 40 Ad Artemidorum, Pinxisti venerem [colis Artemidorem, Minervam] Et miraris opus displicuisse 


\section{El Niño con su Padre de Fray Diego Padilla}

\section{El niño con su padre}

N. Papá, dígame V. ¿solamente ese librito está prohibido?

P. No, hijo mío, hay muchos libros, que no se pueden leer sin incurrir en anatema, como son los impuros, tales como la nueva Teología [Eloysa o Heloisa] ${ }^{38}$ peor que la vieja, y los heréticos, tales como los de Rousseau, y los de Voltaire.

N. ¿Quién [es] ese Rousseau?

P. En este libro te puedes imponer quien es ese ministro del infierno. Lee.

N. Esto está en francés.

P. Pues tradúcelo al castellano. / [26]

N. Papá: todavía no sé traducir bien esa lengua.

P. No obstante, tradúcela como puedas, y te servirá de lección.

N. Dice así: "Predicción de un viejo manuscrito sobre la nueva Heloisa, Romance de J. J. Rousseau. ¿Va bien? Papá. ${ }^{39}$

P. Si, bien traducido está, prosigue.

N. Pues dice así: “En estos tiempos aparecerá en Francia un hombre extraordinario, venido de las márgenes de un lago; y gritará al pueblo: yo estoy poseído del demonio del entusiasmo: yo he recibido del Cielo el don de la inconsecuencia: yo soy filósofo, y profesor de paradojas"

"La multitud de simples le seguirá, y muchos le creerán...."

"El les dirá: todos vosotros sois sceleratos [sic: sceleratus = malvados] y bribones: vuestras esposas son todas mujeres perdidas: yo vengo á vivir, no obstante con vosotros. El abusará de la dulzura, y candor del pueblo, para / [27] decirles injurias absurdas."

"El añadirá: todos los hombres son virtuosos en el país en que yo nací, pero jamás volveré yo a habitar entre ellos."

N. Papá, ¿va bien la traducción?

P. Sí, hijo mío, bien va; prosigue.

N. Dice así: “El añadirá, que las ciencias, y la artes corrompen necesariamente las costumbres; y no obstante escribirá sobre las ciencias, y las artes. El sostendrá, que el teatro es la causa de la prostitución y de la corrupción; y él hará otras, óperas y comedias."

"El escribirá, que sólo entre los salvajes hay virtud; aunque él no haya vivido jamás entre ellos; y aunque sea digno de habitar con ellos. ${ }^{40}$ El dirá, que todos, los grandes son unos

tuum? Heriste a Venus. Y miras tu obra desagradable. Se trata de un escarnio que hace al pintor Artimidore.

38 En la p. 40, como luego veremos aparece en nota: ERRATA.- En el No. 4, pág. 24, lin. 6, dice: nueva Teología, lee nueva Heloisa.

39 Se ve que tenía una de las primeras ediciones o un manuscrito de Julie ou La Nouvelle Heloise de Rousseau, que aparece como editor de cartas con notas, que son un anticipo del Contrato social.

40 El P. Padilla, que sí visitó las misiones y vio a los aborígenes salvajes, se dio cuenta de que Rousseau desconocía la realidad de estos pueblos que de suyo eran religiosos a su manera. 
menospreciables criados; y al mismo tiempo frecuentará y hará muchas sumisiones á los grandes."

"El dirá, que la música francesa no vale nada; y con todo eso / [28] ${ }^{41}$ se ocupará en copiar piezas de la música francesa."

"El dirá, que es imposible tener buenas costumbres leyendo romances, y él hará un romance, y en su romance se verá el vicio en acción, y la virtud en palabras; y los personajes del romance serán poseídos de las furias del amor y de la filosofía."

"El procurará hacer creer á todo el mundo, que sabe escribir cartas amorosas, y que las ha recibido de... [sic]. Y en su romance se enseñará el arte de sobornar filosóficamente una joven doncella."

“Tendrá una discípula; y esta perderá todo pudor, y vergüenza, y aprenderá todas sus máximas y locuras, llenándose de ideas metafísicas, y sus billetes [cartas] serán homilías filosóficas".

“El Filósofo le enseñará, que los Padres no tienen alguna autoridad sobre las hijas cuanto a la elección de esposos, y se los pintará / [29] como bárbaros, y desnaturalizados" ${ }^{\prime 2}$.

“El rehusará recibir honorarios del Padre de su discípula, por la natural delicadeza que tiene todo el que teme una pena aflictiva; pero él recibirá ocultamiento el dinero que a escondidas le regala su discípula; y él probará que esto es justo y honesto."

“El irá á París y no frecuentará gentes sensatas y honestas sino mujercillas y artesanos y dirá, que ha visto á París". ${ }^{43}$

"El querrá matarse, y hará una larga disertación para probar que un hombre por celos debe matarse, y por persuasiones de su amigo no cometerá el suicido; pero se irá al rededor del mundo para dar tiempo á que crezcan los hijos de su discípula; para después volver á ser su Preceptor, y enseñarles la virtud, como se la enseñó á su madre.

"El hallándose en su Elíseo procurará arrojar á su discípula en / [30] un pozo, y precipitarse con ella, y dirá, que todo eso es virtud y filosofía."

"A fuerza de hablar de filosofía, y de virtud, no se comprenderá lo que es la virtud, ni la filosofía: pondrá la virtud en el placer, y la filosofía en el arte de hacer interesantes los vicios".

"La discípula criará con mucha virtud á sus hijos, y cuidará con mucho celo el que no se les enseñe que hay un Dios. Ella será pedante en el hablar y hará desprecio de todas las mujeres".

"El y ella amarán el vino, se embriagarán y dirán cosas dignas de taparse los oídos; y añadirán, que solos los borrachos son gente honrada".

"La discípula para morir se vestirá como se visten las prostitutas, y dirá al filósofo, que ella muere como ha vivido, y se dirá, que ella ha muerto como una Santa."

"El libro que entre los dos han / [31] compuesto será moral, útil y honesto, pues en él se prueba, que las niñas tienen derecho de disponer de su corazón, de su mano, y de sus favores

41 Se hace ver las contradicciones que hay en Rousseau sobre la música y la religión.

42 Los padres tienen derecho y obligación de aconsejar bien a sus hijas, por eso se exigía antes su consentimiento para la licitud del matrimonio.

43 Algunas erratas son de imprenta, donde se cambiaba de letras porque no entendían bien el manuscrito. 
sin consultar con sus padres y sin respecto á la desigualdad de condiciones: y se demuestra en él, que como se habló siempre de virtud, no hay necesidad de practicarla".

“El filósofo probará ó dirá que él prueba, que el amor es inútil entre dos Esposos".

“El libro será escrito en estilo enfático para imponer a los simples, y el autor amontonará frases y creerá amontonar razones: él acumulará exageraciones, y jamás pondrá excepciones; querrá parecer nervioso y no será más que un atolondrado, él cuidará de concluir siempre del particular al general; y el sarcasmo le servirá de razón".

“Todo el talento del autor será dar á la virtud insultos y al buen sentido puntapiés: él emponzoñará / [32] las almas, y dirá que quiere curarlas: El se gloriará de haber abierto un precipicio y se excusará diciendo: tanto peor para las niñas que cayeren en él; yo se lo advertí en el prefacio del libro, pero las niñas jamás leen los prefacios. ${ }^{44}$

"Y después que en su obra habrá degradado las costumbres por la filosofía, y la filosofía por las costumbres, dirá, que á un pueblo corrompido le conviene tales romances" 45 (a).

N. Papá, Yo no leo más esto: el autor me parece un loco.

P. Es uno de los principales corifeos, que estiman en mucho los incrédulos: haces muy bien en no continuar leyendo, porque lo que sigue es muy indecente. Pero cuando tu tío venga esta noche reléele lo que has traducido y pregúntale ¿si por hay [ahí], ha visto algunos retratos parecidos á este original.

\section{Bogotá}

Imp. De Espinosa, por Valentín Rodríguez Molano. Año de 1824.

\section{Núm. $5^{\circ}$ Bogotá, domingo, 18 de julio, 1824}

Loquevatur penitus contraria, tacit. in-trver. ${ }^{46}$ [Se decía en el fondo lo contrario] ${ }^{47}$

\section{El niño con su Padre}

N. Papá: hice á mi tío la pregunta, que V. me previno, y respondió, que conocía algunos, que como J. J. llevaban siempre el pro y el contra. ¿Dígame V. qué quiere decir: llevar el pro y el contra ${ }^{48}$

P. Quiere decir: que el que habla, se contradice, que tan presto afirma, como niega, que habiendo asegurado que una cosa es blanca, luego dice, que es negra.

\footnotetext{
44 J. J. Rousseau puso un "Prefacio" en la segunda edición con una conversación entre el editor y un hombre de letras, justificando algunos pasajes eróticos por su propio corazón y el objeto de sus escritos.

45 (a) Journ. Enciclop. T. 3. Cita tomada de La Enciclopedia Francesa. Aquí se ve que tenía ejemplares de la Enciclopedia Francesa, de la que tomó textos.

46 In-trer. Luego en la p. 41 pone Tacit. in Tiber.

47 Cornelio Tácito tiene frases parecidas, lo mismo que otros, como san Agustín, para indicar que se dice lo contrario de lo que interiormente se piensa. Sucede esto con la historia que no corresponde a veces con la realidad. Hay contradicciones. Lo utilizaron los sofistas y ha tenido sus seguidores.

48 Este método fue utilizado por Abelardo, con el sic et non, y sus seguidores para inquirir la verdad, aunque se usó a veces como los sofistas, ocultando la verdad, por razones políticas o de otra índole.
} 
N. Papá; ¿y el tal J. J. es de ese carácter?

P. ¿Pues no lo viste en la traducción, que hiciste el otro día?

N. Pero yo pensaba, que en sus otros escritos (por que mi tío dijo, que eran muchos) usaría de más formalidad. / [34]

P. Pues te equivocaste en ese juicio; porque en todos sus papeles está la contradicción, ó como decía Tulio ${ }^{49}$, el pro y el contra: y si no, atiende, y veras cómo es cierto lo que te digo.

N. Sí, Papá, lo tengo por cierto, solo por que V. me lo dice, y sin necesitar de pruebas; pero gustaría de oír á V.

P. Pues oíd: primero dice, que a los niños y niñas no se les debe hablar de Dios, ni enseñarles el Catecismo hasta la edad de diez y ocho ó veinte años, por que antes no pueden tener idea de Dios (a),$^{50}$ y luego dice, que quiere enseñar a las niñitas desde su tierna edad, porque si fuese preciso aguardar á que fuesen grandes, y capaces de discurrir, se pondría á riesgo de no poder nunca enseñarlas $(b)^{51}$. ¿No ves ahí el pro y el contra? ${ }^{52}$

N. Lo veo en verdad; ¿pero cuál de los dos extremos le parece á V. más conveniente?

P. Ya sabes, que la primera obligación del hombre cuando entra en el uso de la razón, es adorar y amar á Dios. ¿Te parece, que el que no sabe, si hay Dios, le podrá amar, y adorar?

N. Es así Papá, que no podrá. Y ahora advierto, que toda la instancia con que V. y mi Mamá nos enseñaban todos los días, y todas las noches; que hay un Dios, á quien no podíamos ver con los ojos del cuerpo, porque es un espíritu purísimo, que está en todas partes, y que este Dios es tan bueno, que sin necesitar de nosotros lo crió á V. y á mí y a todos, y nos sustenta y nos redimió del infierno, y otras tantas cosas, que nos decían, era para que cuando fuéramos grandes, y tuviéramos juicio, adoráramos, y amáramos á Dios.

P. Sí, hijo mío ese era el fin, conque tu Madre, y yo os enseñábamos.

N. Es verdad, Papá, que entonces, como era yo chiquito, no atendía/[36] ni hacía caso de lo que $\mathrm{V}$. me enseñaba, pero se me quedaba en la memoria, y ya cuando fui creciendo, me acordé de lo que me habían dicho, y como que se me abrieron los ojos, y empecé á recapacitar.

P. ¿Y entonces que hiciste?

N. Me postré de rodillas, adoré á Dios, le di gracias, conforme V. me había enseñado, y le prometí hacer todo lo que me mandase.

P. Cumpliste con tu obligación.

49 M. Tulio Cicerón pone el pro y el contra al tratar sobre la naturaleza de los dioses. J. J. Rousseau cita a Cicerón en Emilio o De la educación, lib. 4, ed. Ángeles Cardona de Gilbert y Agustín González, Gallego (Barcelona: Bruguera, 1975), 480.

50 (a) Emil. T 2.

51 (b) Emil. 2. [y] 4. p. 72. [Es aquí donde trata de la religión de las niñas] Se buscó en las ediciones que hay en la Biblioteca de Viena y no coincidía con ninguna de ellas.

52 J. J. Rousseau afirmó que el niño es incapaz de comprender los conceptos religiosos complejos y los aceptarán o seguirán. Según él, no lo creerán a pesar de que lo repitan. Para él "es un mal menor ser ignorante de Dios que ofenderlo". Esto es un error con contradicciones. Jesús dijo: "Dejad que los niños se acerquen a mí" (Lc. 18, 16). Rousseau quería alejarles. Al tratar del contrato social, termina con un inesperado capítulo: "Sobre la religión civil". Rechaza todas las religiones positivas y acepta sólo la natural, aunque luego reconoció al Evangelio como el más hermoso de los libros. Su profesión de fe cristiana parece un credo sentimental, negando lo sobrenatural. Lleva a un materialismo ateo. 
N. Pero, Papá, los que hasta la edad de 20 años no saben si hay Dios, ni se les debe hablar de Dios, como dice ese hombre J. J. ¿cuándo podrán aprender esa obligación?

Porque el negrito Miguel que nos sirve no tiene 20 años, y ya es casado, y todo el día está en su trabajo, y no tiene momento desocupado para aprender el Catecismo; con que si de chiquito no lo hubiera aprendido, se muriera sin aprenderlo, sin saber que hay Dios, sin adorarle, y sin amarle. / [37]

P. Discurres bien, porque ese caballero J. J. dice, que á la gente del pueblo tampoco se le debe enseñar que hay un Dios hasta esa edad.

N. Y dígame, Papá, ¿si los niños en edad de 16 años se mueren sin saber que hay Dios, sin adorarle, y sin amarle, se irán al Cielo? Porque sin conocer a Dios, no podrán arrepentirse de sus pecados, ni pedir misericordia, y sin saber el Catecismo, no sabrán qué pecados tienen, ni se podrán confesar.

P. Así es, hijo mío, ¿pero qué quieres que te diga, sino lo que dijo Jesucristo: el que no creyere, se condenarán ${ }^{33}(\mathrm{c})$

N. Con que los niñitos chiquitos que se mueren, no se pueden salvar; por que no conocen á Dios, ni lo adoran, ni tienen fe.

P. Los niños que mueren antes de tener uso de razón se salvan estando bautizados, porque aunque no hagan actos de fe, en el bautismo / [38] se les infunden los hábitos de fe, de esperanza, y caridad, y les aprovecha la fe de sus padrinos, que responden á nombre del bautizado.

N. ¿Y si mueren después de tener uso de razón sin haber conocido, ni adorado, ni amado á Dios

P. Una cosa es no conocer á Dios, otra no quererle conocer ${ }^{54}$ (d). El que ignora, por que no quiere instruirse, peca; y el que muere en esta culpa voluntaria, se condena. Un joven de 16 años, nacido entre cristianos, si ignora la ley, es porque no quiere aprenderla. El que por negligencia no la aprende, vive en pecado, y muere en pecado, si muere en esta ignorancia.

N. ¿Pero si ignora la ley por que sus Padres no se la enseñan, y no quieren que se le hable de Dios, ni de ley?

P. La ignorancia de aquellos no les excusa del infierno, si absolutamente no creyeron; pero porque de ningún modo oyeron, tal vez tendrán menos tormentos en el infierno, porque ninguno puede tener ignorancia invencible de la existencia de un Dios, y de la obligación de amarle..$^{55}$ (e)

N. ¿Pero la culpa será de sus Padres que no les enseñaron. / [39]

P. Sus Padres son reos de esa culpa; pero eso no quita que los hijos lo sean también. ¿No has leído en la Constitución del Estado, que para poder ser Senador, es preciso tener una propiedad de valor de cuatro mil pesos? ${ }^{56}$

53 (c) Marc. 16. 16.

54 San Agustín, De la gracia y del libre albedrío, vol. VI, c. 3, n. 5, en Obras Completas (Madrid: BAC, 1959), 226-227. Aparece la cita así: (d) S. otug. De Gran et lib. Arb. C. 3. Está bien la cita y mal la palabra de San Agustín. Se cometían los errores al imprimir sin la corrección de pruebas.

55 (e) Ibíd. La idea aparece en Ibíd. c 3, donde se menciona un texto de san Lucas, 12, 48. Se aclara esto en otros capítulos del mismo libro De la gracia y del libre albedrío de san Agustín.

56 Constitución de Colombia de 1821, art. 95, 4. Para senador se requería ser "dueño de un principal que alcance al valor libre de cuatro mil pesos en bienes raíces o en su defecto el usufructo o renta de quinientos pesos anuales o ser profesor de alguna ciencia”. 
N. Así lo dice la Constitución.

P. Pues dime: ¿Si un pobre que no tiene esa cantidad, pretendiese ser Senador, le valdría alegar, que si era pobre era por que su Padre había disipado su herencia, y no le había enseñado, ni permitido aprender algún oficio, para formar su capital de 4000 pesos?

N. No, Papá, ¿no le valdría ese alegato contra la ley.

P. Pues ¿si en un Tribunal terreno no vale la excusa de que su Padre no le enseñó oficio para juntar 4000 pesos, en el Tribunal de Dios valdrá la excusa de que mi Padre no me enseñó el Catecismo? No: el uno no entrará en el Senado, por que no tuvo dinero, y el otro no entrará en el Cielo, porque no tuvo fe.

N. Pero, Papá, ¿le parece á V. justo el que este joven se condene porque no le enseñaron el Catecismo?

P. ¿Y te parece justo, que el otro joven no sea Senador por que su Padre no le proporcionó medios para juntar 4000 pesos? / [40]

N. Sí, Papá, porque la ley lo dice.

P. Pues la ley de Jesucristo está expresa: el que no creyere se condenará. ${ }^{57} \mathrm{Y}$ advierte, que si el joven que muere sin fe, no tuviere pecado personal que merezca el infierno, levantará el pecado de su primer $\mathrm{Padre}^{58}$ (f) cómo le bastará al otro la negligencia de su Padre para no poder entrar en el Senado.

N. Pero me asombro el que J. J. quiera que los niños con ese riesgo no tengan religión.

P. No, hijo mío, J. J. quiere que tengan Religión. (g) ${ }^{59}$

N. Pero, Papá, ¿podrá haber Religión sin conocer un Dios?

P. No te dijo tu tío, que ese caballero y sus semejantes llevan siempre el pro y el contra?

N. Es verdad; pero les hace á los niños muy poco favor.

P. No les hace más favor a sus Madres.

Errata. En el N. 4, p. 25, línea 6, dice: nueva Teología, lee nueva Eloisa. ${ }^{60}$

Bogotá, Imp. de Espinosa, por ValentínRodríguez Molano, año de 1824

\section{Núm. $6^{\circ}$ Bogota, Domingo $1^{\circ}$ de agosto, 1824 [41]}

Loquevatur penitus contraria, Tacit. in tiber. ${ }^{61}$ [Se decía interiormente lo contrario]

57 Marc. 16, 16.

58 (f) S. Aug. Ep. Ad Sisot. Quiere decir San Agustín, Epístola 191 ad Sixtum. De finales de 1 año 418, nn. 32-46., en Obras de San Agustín, vol. IX, Cartas, trad. Lope Cilleruelo (Madrid: BAC, 1991), 87-99. El P. Padilla conocía bien a los Santos Padres, especialmente a san Agustín, que expone este tema también en otros tratados

59 (g) Emil. T. 1, 224. Probablemente se refiera al libro 4, donde acepta la religión natural o positiva. Por esta y otras citas se podrá saber la edición que usó, lo cual resulta difícil por ahora.

60 Ya se observó esto en nota 36.

61 Aparece la cita algo cambiada y mejor. Mikel. Cornelio Tácito es autor de Annales, Germania, Brevioarium vitae Julii Agricolae y Breviarium Historicum. Las palabras In Tiber pudiera referirse a Tiberio o al Tiber. No se ha podido localizar esta cita. 


\section{El niño con su Padre}

N. Papá. V. me dijo, que el Señor J. J. hacía tan poco favor á los niños como á sus madres. ¿Qué es lo que dice de ellas?

P. Las mujeres deben estar muy agradecidas á ese Señor, por que dice, que son unos jumentos, unas borricas incapaces de discurso, ni de raciocinio, y que deben seguir á sus maridos como una bestia sigue al que la lleva con el cabestro ${ }^{62}(a)$. Pero en otra parte ${ }^{63}(b)$ finge una señorita más sabia que Platón, y más discreta que Sócrates.

N. Entonces ese Señor se contradice.

P. ¿No te he dicho, que es de los filósofos del pro y el contra? También / [42] dice, que los maridos las deben inspirar la Religión que se les antoje, y que ellas como puros autómatas deben seguir la creencia de sus esposos, renunciando su entendimiento, por que son incapaces de juzgar, de suerte que si el varón no tiene Religión, por esta regla la mujer no debe tenerla.

N. Papá: eso me parece un disparate.

P. Pero luego lo enmienda, porque pinta á la Señorita Julia como buena protestante, y á su marido como un perdido ateo, y la hace llorar, y procurar de todos modos la conversión de su esposo, sin que este pretenda reducirla á no tener Religión, ni se incomode por las exhortaciones de su mujer, dejando en paz al hombre sin Religión, y á la mujer con ella ${ }^{64}$ (c).

N. Y será verdad, que vivían en paz.

P. El Señor J. J. así lo dice.

N. ¿Pues como dice, que la Señora Julia decía, que el amor que tenía á su marido era su mayor tormento? / [43] Que tener precisión de habitar en un mismo cuarto, y sentarse á una misma mesa, era para ella un martirio, y una desesperación ¿No lo acaba V. de leer ahora? ${ }^{65}$ (d)

P. Cuando tú has reparado en esta contradicción, ella debe ser muy clara. Pero advierte, que una paz simulada es puramente exterior, consiste en aparentar una tranquilidad, que realmente falta, en evitar las riñas, y disgustos que turban el sosiego de las familias, y en disimular los sentimientos del ánimo pero en lo interior en el fondo del corazón, allí no hay paz: la misma Julia confiesa, que no había ocasión de placer, que no fuese acibarada por el extravío de su marido, que si le acompañaba al paseo, si discurría con él, si recibía sus agasajos, se veía precisada á ocultar su dolor; pero que sentía un tormento, que casi llegaba á desesperación ${ }^{66}(\mathrm{e}) . /[44]$

En efecto, ¿Cuantas mujeres se verán precisadas á disimular los extravíos religiosos de sus maridos, y á presentárseles placenteras, risueñas y contentas como la Señora Julia, cuando su corazón está despedazado de dolor, y se consumen, y lloran en secreto?

N. Papá: Entonces mejor era para las mujeres no casarse con esos hombres, si habían de padecer ese tormento.

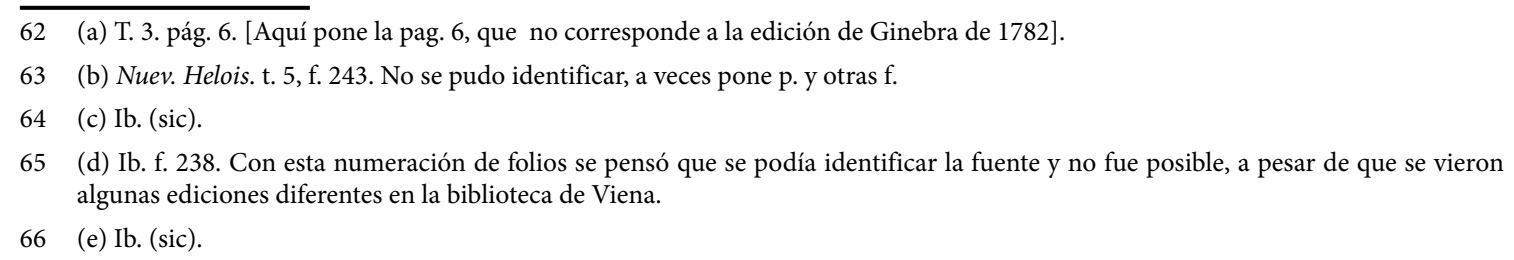


P. Si se hubiera de seguir el sistema del Señor J. J., las mujeres no debían casarse con esos, ni con ningunos.

N. ¿Por qué? Papá.

P. Porque el tal Sr. en una carta ${ }^{67}$ (f) dice mil execraciones contra el Sacramento del Matrimonio. Oíd lo que dice, hablando de los Sacerdotes: los Católicos con una resolución bárbara predican el nudo conyugal. ¿Por qué no se casan ellos? ¿Por qué? / [45] Porque un estado tan santo, ha venido a ser por vuestras imprudentes instituciones un estado infeliz, en el cual es imposible vivir sin ser un malvado, ó un loco: es un cetro de hierro. ¡O leyes insensatas! A vosotras culpamos de no haber podido cumplir nuestras obligaciones. Las leyes que llama insensatas son las de la Iglesia.

N. ¿Porqué llama al matrimonio cetro de hierro?

P. Por su indisolubilidad, ó tal vez porque no permite la poligamia, y esto es lo que le incomoda, como incomoda también á otros señores sus semejantes. Ellos dicen, que la abolición del repudio es la causa de los pesares, y disgustos que sufren los casados: que la indisolubilidad del matrimonio, cuando mas se debe restringir á los pobres y labradores: que no se debe privar á los hombres la satisfacción de mudar esposas, cuando se les antoje: que la poligamia no es más que un negocio de cálculo sobre las expensas y gatos: finalmente lo que aborrece el Sr. J. J. es la ley que estableció N. Sr. Jesucristo, y consta en el c. 19 de S. Mateo, ${ }^{68}$ y la decisión del Concilio Tridentino en la sesión 24, De matrimonio c. 2, que dice así: si alguno / [46] dijere que á los Cristianos es lícito tener muchas mujeres á un tiempo, y que esto no está prohibido por ninguna ley divina, sea excomulgado. ${ }^{69}$

N. Conque entonces el Sr. Juan Jacobo y esos otros señores á quien llaman imprudente, y bárbaro ¿es á N. S. Jesucristo?

P. Así es, hijo mío, que blasfeman esos filósofos: así es que inculpan á Dios, y al Sagrado Concilio, diciendo, como dice J. J. que las sagradas instituciones son la causa de sus desgracias que por estas santas instituciones es, que no pueden los filósofos cumplir con sus obligaciones: que por estas instituciones, que él llama bárbaras, e imprudentes se ha convertido el estado santo del matrimonio en un estado infeliz, y ridiculo, en el cual es imposible vivir sin ser un malvado ó un loco; contra estas sagradas instituciones, es que dice, que la naturaleza levanta la voz para quejarse de su barbarie, porque han reducido á los hombres á la miseria. Estas leyes santas son las que llama insensatas y cetro de hierro.

N. Pues si esos señores aborrecen el matrimonio, y lo llaman cetro de hierro, querrán que todos los hombres sean clérigos y frailes, y que todas las mujeres sean monjas.

P. Peor es eso, porque esa gente / [47] aborrece más á los clérigos y frailes que á las sagradas instituciones del Sacramento del Matrimonio. Dice, que el Matrimonio...

N. Papá ¿por qué aborrecen á los clérigos y frailes?

P. No me interrumpas: estamos hablando del Matrimonio: otro día satisfaré á esa tu pregunta. Dice pues, que el Matrimonio es de obligación á todo hombre, porque todo hombre lleva un grande enemigo consigo, y que es de derecho natural. Pero luego dice, que es conveniente,

67 (f) 73. Según Rousseau, el matrimonio no es sacramento sino un contrato civil. Consideró al celibato como antinatural y que el voto de castidad no debería permitirse por el poder civil. Él hizo mucho daño.

68 Mat 19, 3-10

69 Concilio de Trento, ses. 24, cap. 2, en Conciliorum Oecumenicorum Decreta, ed. J. Alberigo y otros (Bolonia: Instituto per le scienze religiose, 1973), 757. Aquí dio bien la cita en el texto. 
que los grandes señores, los ricos, y los poderosos no se casen, y les dispensa en la ley, que dice de la naturaleza; les dispensa también el llevar consigo el formidable enemigo que llevan consigo todos los hombres; y como ha dicho, que los que no se casan, no son hombres, les dispensa también el que puedan ser hombres sin casarse: y finalmente como ha asegurado, que sólo los jornaleros, los artesanos, y villanos son verdaderamente útiles á un estado, parece que á los que dominan, y á los ricos y grandes les habrá de dispensar para que en alguna cosa puedan ser útiles, aunque no verdaderamente, según dice este tal Señor. De suerte que la ley de la naturaleza solo se hizo para la gente pobre y miserable, solamente éstos / [48] llevan consigo el enemigo terrible, sólo ellos son hombres, y sólo ellos son verdaderamente útiles á la patria, según J. J. Rousseau. Verdaderamente los ricos y poderosos deben ser muy agradecidos á este caballero.

N. Papá: Me parece, que en esas pocas palabras ha dicho ese hombre muchas contradicciones, y disparates, que me causan admiración.

P. Mas admiración te debe causar el que haya quien lo lea, quien lo elogie y á ciegas crea lo que dice.

N. ¿Y todo eso lo habrá él sacado de su cabeza, ú otros se lo habrán dicho?

P. Algunos rasgos son originales de su pluma, que lo más es copiado de otros incrédulos, que han corrompido la moral, é insultado el Evangelio, como después verás, porque quiero instruirte, para que no te dejes seducir de esos filósofos, que prodigan alabanzas á una filosofía corruptora, inmoral, y perversa. No leas esos sofistas, no te acompañes con los que siguen sus errores, huye de esos áspides venenosos, que matan con solo su aliento.

N. Así lo haré con la gracia de Dios.

Imp. de Espinosa, por Valentín Rodríguez Molano. Año de 1824

Núm. $7^{\circ}$ y último Bogotá, Domingo 8 de agosto, de 1824 [49]

Príncipus obsta. ${ }^{70}$ [Resiste desde el primer momento]

\section{El Niño con su padre}

N. ¿No sabe V. Papá, que ya todas las escuelas se han cerrado, y que todos los niños están en vacaciones?

P. Sí, hijo mío, ya lo sé, ¿pero tú que quieres decirme con esa pregunta? ¿También quieres usar del asueto que se concede á los estudiantes en este tiempo?

N. Si á V. le parece bien, yo querría, que me concediese algunos días de descanso para divertirme en este asueto.

P. Tienes razón, y aunque deseaba en estos días acabar de instruirte sobre la persona, y doctrina de Sr. J. Jacobo y de los otros filósofos de su tiempo; pero veo, que tienes justicia en pedirme las vacaciones acostumbradas.

70 Publio Ovidio, Remedia amoris, versos 91-92: Principiis obsta: sero paratur/ cum mala per longas convaluere mora. [Resiste desde el primer momento, la medicina llega tarde/cuando el mal se ha fortalecido]. En Ars Amatoria, ed. y trad. José Ignacio Ciruelo (Barcelona: ed. Bilingüe s.a.), 220-221. 
N. ¿Y por qué desea V. tanto el instruirme en las personas, y escritos de esos señores?

P. Porque la obligación de un Padre es instruir á sus hijos en el riesgo y males que causan las malas compañías. Veo que vas creciendo como espuma, y que en estando más grandecito, te han de echar el ojo los filósofos, para llevarte á su partido / [50]: á excusas mías te han de hacer mil elogios de los incrédulos; te ponderarán la sabiduría de Voltaire, aunque él no fuese más que un sofista; la honestidad de Rousseau, aunque no fue sino un corruptor, por lo que fue desterrado de Francia; el ingenio de Oves, [Hobbes] ${ }^{71}$ de Alamber [D'Alembert] ${ }^{72}$ de Baile, etc., ${ }^{73}$ aunque no fuesen más que hombres carnales, y espíritus fuertes. Y después habiéndote hecho formar estimación de estos y otros filósofos, te inspirarán curiosidad por ver sus escritos, ellos te los proporcionarán; te pondrán en la mano las cartas filosóficas, la muchacha de Orleans, el tratado de la tolerancia, y otras obras de Voltaire; luego te presentarán el Espíritu [De l'Esprit 1758] de Helvecio, de los filósofos modernos, la nueva Eloisa y el Emilio de Rousseau, el amor socrático del Diccionario filosófico, el sistema de la naturaleza, ${ }^{74}$ y otros libritos impíos, sucios, y deshonestos y te querrán persuadir, á que nada tienen de malo, que sus autores son sabios, modestos y religiosos, y que su doctrina es útil, necesaria y conveniente par ilustrar el entendimiento, para salir de preocupaciones, para practicar la virtud, y ser hombre de espíritu, de moda y de estimación.

Quiero prevenirte con tiempo, para que no te dejes seducir, para que sepas, que esos autores son herejes, malvados, [51] corruptores, enemigos de Dios, precursores del Anticristo, ó la cuarta bestia del Apocalipsis. Ya te lo prevengo, hijo mío: si no quieres precipitarte en un abismo, no des un paso hacia él; la piedra que se arranca de la sima de un monte no se para, corre precipitada, y mientras más baja, mas se apresura á llegar al valle: lo mismo sucede en nuestro caso. Malo es que un hombre afloje, y dé un paso fuera del monte de la religión, porque en el momento se precipita. Por ejemplo: oye un joven elogiar las poesías y gracias de Voltaire; la curiosidad le infunde deseos de leerlas, atropella las censuras, y las lee: como la conciencia es un fiscal importuno, se reconoce incurso en anatema. ¿Qué remedio? Busca pretextos, y sofisterías par negar el valor de las censuras; cómo estas son vibradas por la Iglesia, se precipita á dudar de la legitimidad o de la facultad de imponerlas. Como no puede hallar fundamento que destruía la facultad que Jesucristo dio á la Iglesia, torna sus miras hacia J. C. mismo, de ahí vienen las altercaciones sobre sus milagros, las invectivas sobre su doctrina, las blasfemias sobre su divinidad. La carrera no para en esto: no pudiendo aquietar sus temores, ocurre á buscar en la filosofía, en la cronología, / [52] en la historia con que negar sus remordimientos, y por un terrible, pero justo castigo de su presunción, se le presentan historias fabulosas, cronologías imaginarias, sofísticos y embusteros raciocinios, que los dejan perplejos, y dudosos, y que los conducen al pirronismo, al deísmo, y al ateismo. Tan cierto es lo que dijo un poeta, que es fácil la bajada al infierno. Pero habiendo llegado á la profundidad, joh Dios! ya no hay remedio: ni la razón, ni la autoridad, ni los remordimientos de la conciencia bastan á hacerle dar un paso atrás; porque en llegando el pecador á lo profundo de faltar á la fé, todo lo desprecia, dice el Espíritu Santo.

71 Tomás Hobbes (88-1679) es autor de varios libros como el Leviatán, donde aparece su teoría del Estado, tomando el título de la bestia de que habla el Libro de Job, 3, 8 y 40, 25; Salmo 74, 14.

72 Jean le Rond d'Alambert (1717-1783) fue expósito a la puerta de la iglesia de Saint Jean le Rond, de donde tomó el nombre. Fue con Diderot el promotor principal de $L$ 'Encyclopèdie y sobresalió en el campo de las matemáticas

73 Pierre Bayle (1647-1706) escribió Dictionnaire historique et critique, con una crítica aguda y negativa de cuestiones históricas y religiosas. Era escéptico y defiende un aparcamiento de la religión. Ha sido seguido por los enemigos del cristianismo.

74 Pablo Enrique Thiry, Barón de Holbach (1723-1789), autor de Systeme de la Nature au des lois du Monde Physique et du Monde moral (Londres Ámsterdam: Leyden, 1770). Se trata de un manual ateo. El P. Padilla hizo una censura al tratado Sistema de la Naturaleza del Barón d'Holbach, con notas de Diderot, que se encuentra en el f. 13, de un códice manuscrito titulado Diccionario filosófico, teológico y científico que se halla en la Biblioteca Nacional de Colombia, ms. 416. 1. Este ms. tiene 157 folios y es del P. Padilla; al menos lo tuvo y lo completó con varias letras, como se ha observado anteriormente. 
N. ¡Jesús! Que V. me hace estremecer con los riesgos que me amenazan. Ya no quiero tal asueto; instrúyame y defiéndame, Papá de esos peligros: yo renuncio ya de esas vacaciones.

P. No, hijo mío, bien puedes usar de ellas, porque aun no estás en peligro inminente; todavía eres chico, y te iré instruyendo para cuando haya riesgo. Usa de las vacaciones, pero que tus vacaciones sean prudentes, y provechosas, tanto para tu salud, como para tu aprovechamiento.

N. Dígame V. como me he de portar en ellas. / [53]

P. Quiero decir, que no sea todo pasatiempo; que le des su tiempo á la Religión, algún tiempo al estudio y todo el demás tiempo á la diversión. Por ejemplo: antes oías misa á las cinco, y comenzabas el estudio á las siete: ahora empiézalo á las ocho, y que dure hasta las diez; desde esa hora empiece la diversión hasta la noche, en la que puedes estudiar otras dos horas. ¿Quieres proporcionarte un buen antídoto contra la seducción de los incrédulos? Aplícate en estas vacaciones á aprender la lengua latina.

N. ¡Ay! Papá, que vacaciones me ordena V. si la lengua latina es tan difícil.

P. Nada hay difícil para el que tiene aplicación; además que no es tan difícil, como te parece. En un autor ${ }^{75}$ (a) he leído, que en dos ó tres meses enseñó á un niño las lenguas latina, griega, é inglesa; y otro dice $[\mathrm{b}]^{76}$ que en ocho días se puede aprender la latina.

N. Pero Papá ¿de qué sirve ya la lengua latina? Yo he oído decir, que ya es una lengua muerta, que no se necesita y que no se debe hablar aun en conclusiones sino en lengua castellana, y se burlan de los que hablan en latín. / [54]

P. Tú no sabes cual es el objeto que tienen los nuevos filósofos en querer, que se olvide el latín.

N. ¿Cual es el objeto?

P. Quitar á los cristianos las armas con que defienden la fe católica. Sobre esto debes advertir dos cosas. La primera es, que todos los dogmas, y los preceptos de moral los tenemos en latín: en latín están todos los concilios generales y sínodos provinciales en latín están todas las obras de los Santos Padres, todos los expositores de la Biblia, todos los controversistas, todas las Bulas de los Papas, todo el Derecho Canónico, todas las decisiones de las diversas congregaciones, todo en fin lo que conduce á la fe, al culto, á la moral y ceremonial de la Iglesia. Quita la lengua latina y con solo esto, serán inútiles para nosotros todos esos preciosos, divinos y magistrales libros. Lo segundo, que debes advertir, es, que todos los argumentos de que usan los incrédulos son copiados de los antiguos herejes, y que en latín los han rebatido los Santos Padres, y en latín han sido condenados por los concilios. Los herejes han renovado los antiguos sofismas en sus libritos; pero no han publicado las soluciones; y para que no aparezcan estas, procuran que se olvide el latín, ¿cómo responden a / [55 $]^{77}$ los Arrianos, sino se entiende el latín de San Hilario? ${ }^{78}$ Como á los libertinos que niegan la Encarnación del Verbo, si no se entiende el latín de Santo Tomás en los 26 capítulos en que destruye los sofismas que ha renovado el autor del

75 (a) D'Aguess. (sic).

76 (b) Caramuel. Juan Caramuel fue monje cisterciense español (1606-1682), un gran filólogo y latinista que estuvo en el monasterio de la Santa Espina, cerca de Medina de Rioseco, en el monte de Torozos (Valladolid), donde Felipe II conoció a su hermano Don Juan de Austria (Jeromín).

77 Aunque se pasa de la p. 55 a la 59 se trata de un error de paginación, ya que es 46. Lo exige el sentido y que cada número lleva tres folios.

78 San Hilario de Poitier (315-367), autor de un libro sobre la Trinidad, donde refutó la doctrina arriana. San Agustín le consideró “un glorioso defensor de la fe". Sus obras y las de otros Santos Padres se encontraban en la biblioteca del convento San Agustín de Bogotá. 
Examen de la Religión ${ }^{79}$ ¿cómo á los judíos, á los paganos, á los herejes, sino se entiende el latín de San Agustín? Verdaderamente, así como un conquistador para humillar una plaza, procura apoderarse de la artillería, y quitar las armas á los contrarios; así los incrédulos pretenden apoderarse de las armas de los católicos, que están como en un parque encerrados en el latín. Tal vez te dirán, que esos libros latinos se pueden verter al castellano. Pero además de que hoy día no se hacen traducciones, sino de libritos impuros e irreligiosos, ¿quien, ni cuando traducir una infinidad de volúmenes que componen todas las obras de que te he hablado?

N. Me parece, que por lo que toca á la religión católica, es una verdad lo que V. me dice: pero para las ciencias sucederá lo mismo.

P. Bastaba el que la lengua latina fuese útil á la Religión, para que todos se empeñasen en aprenderla: pero como los iluminados pretender dejar al mundo en tinieblas / [59 $]^{80}$ también quieren quitar este auxilio á las ciencias. Casi todas están en latín: la jurisprudencia, empezando desde el Vinnio [Arnol de] ${ }^{81}$, está en latín: en latín escribieron las matemáticas Newton, Wolfio ${ }^{82}$ Gravesand, ${ }^{83}$ Brixia, $^{84}$ Bacón [Francisco] etc. ${ }^{85}$ la filosofía de Purchot, ${ }^{86}$ de Corsini $^{87}$ y otras están en latín; los historiadores, los poetas, los oradores, toda quasi la literatura está en lengua latina, de suerte, que desterrando el estudio de esta lengua, ya los impíos conseguirían no sólo propagar sin oposición sus errores, sino también destruir todos los conocimientos científicos: dad al fuego, decían los Jacobinos de Francia, dad al fuego esas viejas bibliotecas que no sirven sino para sostener la superstición, y el fanatismo de los católicos. En efecto entre otras muchas quemaron la gran biblioteca de San Germán. ${ }^{88}$

Por lo cual, ó hijo mío, yo quiero que aprendas ese idioma, aplícate á estudiarlo en estas vacaciones; y te ofrezco poner en tus manos unos libros preciosos, en que te desengañes, y estés prevenido contra los sofismas, supercherías y engaños de los nuevos filósofos, de esos espíritus fuertes que con pretexto de ilustrar al mundo, quieren sepultarlo en las tinieblas.

Bogotá.- Impr. de Espinosa, por Valentín Rodríguez Molano. Año de 1824.

79 César Cherneu du Marsais (1676-1756), autor de Examen de la religión in cherche l'ecaircissement de bona foy, que se publicó en el tomo XII de la Enyiclopèdie, en 1765, 9 años después de su muerte. Se atribuyó algún tiempo a Saint-Evremont, pero se reconoció la autoría de Du Marsais, en una carta de D’Alembert, cuando Voltaire hacía la revisión del opúsculo para la Encyclopèdie. Se publicó como opúsculo aparte, que se vendía en París y como artículo con algunas diferencias por las correcciones y mutilaciones, al ser condenada esta obra al fuego y prohibida por el rey.

80 Se pasa de la página 55 a la 59 , que debe ser 56 . Hay continuidad de pensamiento y se debe a un error de paginación.

81 Arnol de Vinnio (1588-1657) es uno de los primeros expositores del Derecho moderno y autor de Cuestiones juris selectae. In quatuor libros mperialium tratatus, etc.,

82 Cristian Woll (1679-1754), autor de Pensamientos racionales sobre... la ilustración (Aufklärung). Había libros de todos estos autores que menciona en el Libro inventario de la librería del Convento San Agustín de Bogotá, que se hizo en 1789 y en 1819. Lamentablemente se da el título de la obra sin indicar lugar y año de la edición.

83 Willem Jacob's Gravessande (1686-1742), autor de Pfysices elementa matemática, experimentis confirmata, sive introductio ad philosophiam Newtonianam. Fue un gran filósofo y matemático.

84 Fortunado de Brixia (1701-1754), autor de Phylosophia, en 4 volúmenes que aparecen en los inventarios de la Biblioteca de la Universidad de San Nicolás y “Biblioteca de la Universidad de San Nicolás en Santafé de Bogota”, en Provincia Agustiniana de Nuestra Señora de Gracia en Colombia, Escritos varios IV (Bogotá: Provincia de Nuestra Señora de Gracia, 2008), 250.

85 Estas obras le eran familiares porque las tenía él en su celda. Eran de la biblioteca del convento.

86 Edmundo Furchot, Instituciones philosoficae ad faciliorem veterum a recentiorem philosophorum lectionem comparatae (París 1695 , 1700 y 1733; Lyon, 1711, 1716-1717; Padua, 1733 y 1751; Amsterdam, 1740, etc.). Este texto era utilizado en bastantes conventos de agustinos, tomo el de Burgos en España y en el de Bogotá. Su nombre latino es Edmundus Furchotius y era francés (1651-1734). Servía en algunos lugares como manual y en otros de consulta.

87 Eduardo Corsini (1702-1765), escolapio que explicaba la filosofía moderna y era buen humanista, además de matemático. Hasta la obra de Karl (Carlos) Marx, Das Kapital. El capital se encuentra en latín en la biblioteca de la Universidad de Tréveris. Me enseñó el original el profesor Klaus Reinhardt.

88 Lo que no preveía él era que la biblioteca del convento San Agustín y de la antigua Universidad de San Nicolás iba a sufrir el fuego de la guerra los días 26 y 27 de febrero de 1862. 


\section{FUENTES}

Archivo del Convento San Agustín de Bogotá (ACAB), donde hay fotocopia de las escritos del P. Diego Francisco Padilla, recopilados en 5 volúmenes por Mauricio Saavedra Monroy en el año 2003.

Biblioteca Nacional de Colombia (BNAC), Fondo Pineda, 726. MF, 213, donde se encuentra El Niño con su Padre. Bogotá: Impr. de Espinosa, por Valentín Rodríguez Molano, 1824. Se consulta en Biblioteca Luis Ángel Arango.

Biblioteca Nacional de Viena, donde se encuentran las obras de J. J. Rousseau, en sus primeras ediciones, especialmente el Emile ou de l'education y Julie, ou la Nouvelle Héloïse.

\section{REFERENCIAS ${ }^{89}$}

Campo del Pozo, Fernando. “Fray Diego F. Padilla, educador y prócer de la Independencia de la Gran Colombia. En Educadores en América Latina y el Caribe de la colonia al siglo XIX y XX, eds. Diana Soto Arango, Jesús Paniagua Pérez, José Rubens Lima Jardilino y María Ctristina Vera de Flachs. Tunja: Ediciones Doce Calles, 2011, 47-81.

Campos y Fernández de Sevilla, F. Javier. El P. Diego Padilla y el "Aviso al Público" (El Escorial: Ediciones Escurialenses (EDES), 2011.

Fernández, Agustín. Oración fúnebre en las honras que hizo el convento de agustinos calzados de Bogotá el día 18 de Mayo de 1820 a la feliz memoria de su hijo y padre N. M. R. P. Diego Francisco Padilla. Bogotá: Imprenta de Bruno Espinosa. Por José Ayarza, 1829.

Padilla, Diego. El Niño con su Padre. Bogotá: Imp. de Espinosa, por Valentín Rodríguez Molano 1824.

Popescu, Oreste. Un Tratado de Economía Politica en Santafé de Bogotá, en 1810. El enigma de Fray Diego Padilla. Bogotá: Imprenta de Salazar, 1968.

Romero, Mario Germán. "Fray Diego Francisco Padilla”. En Próceres 1810 en el Sesquicentenario de la Independencia, eds. Juan Lozano y otros. Bogotá: Banco de la República, 1960.

Rousseau, Jean Jacques. Emile ou de l`Education. La Haye: Chez Jean Néaulme, 1762. (Hay varias ediciones en sus Obras completas de 1765, 1772 y 1782, que pudo usar el P. Diego F. Padilla. En Bogotá y Madrid hay ediciones del siglo XIX).

Rousseau, Jean Jacques. Emilio o la Educación, ed. Ángeles Cardona de Gilbert y Agustín González Gallego. Barcelona: Ediciones Bruguera, 1976, 52-53.

Rousseau, Jean Jacques Julie ou La Nouvelle Héloïse, Lettres de deux amns, Habitans d’une petite Ville su pie des Alpes. Amsterdams: Chez Marc-Michelets Rey, 1761. En 1772 se hizo allí mismo la tercera edición.

89 Aunque la bibliografía sobre el P. Diego Francisco Padilla es abundante, sobre El Niño con su Padre es escasa, porque se desconocía su existencia en la Biblioteca Nacional de Colombia. Algunos se limitaban a citar esta obra como el P. Agustín Fernández, que no es poco. La mayoría ni siquiera la mencionan. 
Saavedra Monroy, Mauricio. Lista crítica de los escritos del Reverendo Padre Diego Francisco Padilla. O.S.A., (1751-1829). Tesina de graduación en el Instituto Agustiniano de Estudios Superiores. Facultad de Filosofía, Bogotá, 2003.

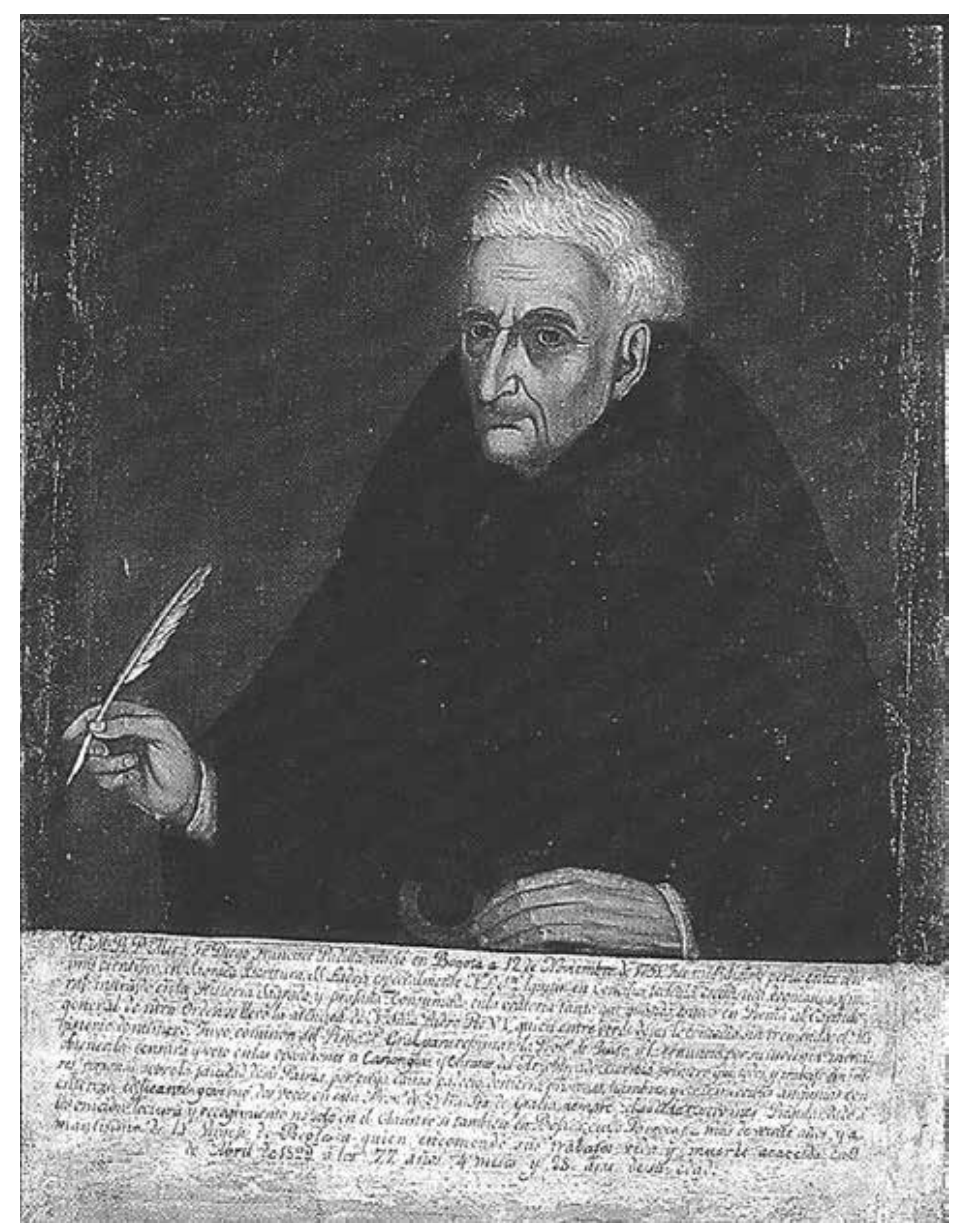

Cuadro al óleo sobre tela de $79 \times 49 \mathrm{~cm}$. De Autor anónimo, pintado hacia 1830. Se conservaba en Bojacá.

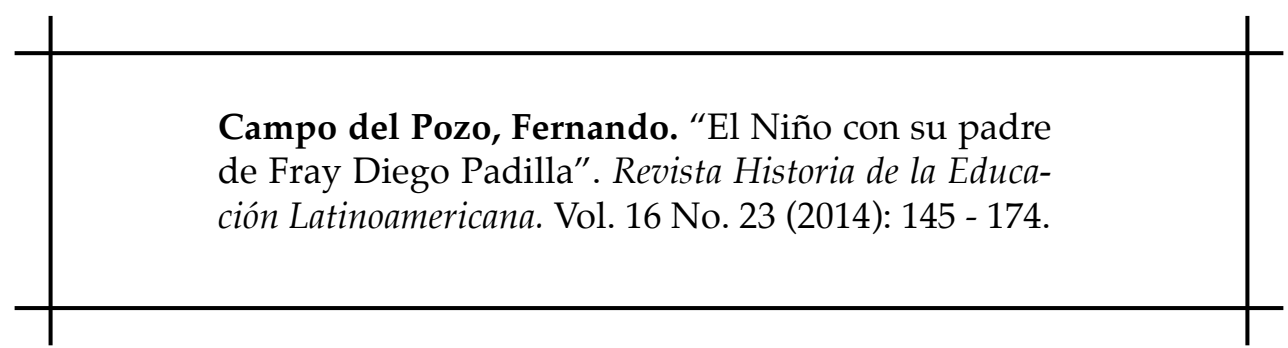

